\title{
PARENTESCO Y PODER: EL ASCENSO SOCIAL DE LA FAMILIA MÚJICA A LA CORTE DE LOS REYES CATÓLICOS*
}

\author{
KINSHIP AND POWER: THE SOCIAL RISE OF THE MÚJICA \\ FAMILY AT THE COURT OF THE CATHOLIC KINGS
}

\author{
ERNESTO GARCÍA FERNÁNDEZ \\ Universidad del País Vasco (UPV/EHU) \\ http://orcid.org/0000-0002-8098-0728
}

\begin{abstract}
Resumen: La documentación escrita referente a las altas instancias políticas del Reino de Castilla a fines de la Edad Media no suele descuidar ni el nombre, ni los servicios encomendados por los reyes a los servidores que sustentaron el entramado institucional del Estado. Ahora bien, no siempre es fácil llegar a conocer los tejidos sociofamiliares en que se cimentó el ascenso de estos administradores y gestores de la Corona, ni tampoco las relaciones establecidas entre ellos y con otras familias destacadas. En este sentido, el entramado sociofamiliar de los Mújica constituye un buen ejemplo de la importancia que tuvieron los lazos de parentesco en su promoción política. Pero no menos relevante es señalar el destacado papel desempeñado por algunas familias de la nobleza no titulada en la construcción de la Corte castellana configurada por los Reyes Católicos.
\end{abstract}

Palabras clave: parentesco; corte; Castilla; poder; Edad Media.

\begin{abstract}
The written documents referring to the high echelons of political power in the Kingdom of Castile at the end of the Middle Ages do not usually overlook either the name or the services entrusted by kings to the servants who upheld the institutional organization of the state. However, it is not always easy to discern the social and family ties on which the rise of these administrators and managers of the Crown was based, or the relationships established between them and with other leading families. In this respect, the Mújica family's social and family ties are a good example of how important kinship was in their political advancement. But it is no less important to stress the outstanding role played by some untitled noble families in the construction of the Castilian court configured by the Catholic Kings.
\end{abstract}

Keywords: kinship; court; Castile; power; Middle Ages.

\footnotetext{
* Se inscribe en el Proyecto de Investigación financiado por el Ministerio de Economía y Competitividad, Poder, sociedad y fiscalidad en el entorno geográfico de la Cornisa Cantábrica en el tránsito del Medievo a la Modernidad, HAR2011-27016-C02-01, con sede en la UPV/EHU. Forma parte del P. Coordinado HAR2011-27016-C02-00, con sede en la UPV/EHU junto con el P. de I. HAR2011-27016-C02-02 de la Universidad de Valladolid. Participa en la Red Arca Comunis, en el Grupo Consolidado de Investigación País Vasco y América. Vínculos y Relaciones Atlánticas y en la UFI 11/02 de la UPV/EHU.
} 


\title{
SUMARIO
}

1. Introducción.-2. Biografía de la familia Mújica y actividades sociales.- 2.1. El padre.- 2.2. Los hijos: Martín, Miguel, Juan y García.- 2.3. Lope García de Mújica.3. Una visión de conjunto.- 4. Conclusiones.- 5. Bibliografía citada.

\begin{abstract}
¡O!, quán mal fortunado es el príncipe y quán desdichada es la república en la qual el pueblo no sirve al señor sino por las mercedes y el señor no los ama ni los defiende sino por los servicios; porque jamás entre los hombres el amor es fixo quando anda algún interesse de por medio.
\end{abstract}

(Guevara 1529, p. 303)

\section{INTRODUCCIÓN ${ }^{1}$}

La frase que he tomado prestada de Fray Antonio de Guevara alude en pocas líneas a las dificultades de los reinos por configurar una urdimbre social sólida, estable, leal y sincera alrededor de la administración regia. Las redes políticas, fiscales y económicas que se tejieron en los siglos bajomedievales en los distintos reinos o ciudades república europeas formaron parte de los complejos entramados económicos y sociales conformados al amparo de los cambios y transformaciones de todo tipo que se operaron durante las centurias decimocuarta y decimoquinta. El estudio de las formas en que se fueron conformando y modificando es de una importancia capital, pues permite aprehender el cambiante funcionamiento de las organizaciones sociales, aunque los hombres de aquella época estuvieron en gran medida atrapados en las estructuras sociales, económicas y de poder en que estaban inmersos ${ }^{2}$.

Estudiar la configuración social de la familia Mújica es una cuestión que importa menos por sus orígenes guipuzcoanos y por su peso político en las instituciones locales y provinciales que por su habilidad, visto a posteriori, para insertarse en las principales redes político-administrativas de la Corona de Castilla. Desde esta última perspectiva me interesa realizar una aproximación histórica a la vida de algunos de los cortesanos de

${ }^{1}$ Abreviaturas utilizadas: AGS = Archivo General de Simancas; ARChV $=$ Archivo de la Real Chancillería de Valladolid; CMC = Contaduría Mayor de Cuentas; RE = Reales Ejecutorias; $\mathrm{RGS}=$ Registro General del Sello.

${ }^{2}$ Trabajo enmarcado en el contexto de la Corona de Castilla, sus administraciones públicas, los servicios a ellas encomendados, etc. Remito a las siguientes publicaciones de interés para situar la problemática de estudio analizada: García de Valdeavellano 1970; Torres 1982; Pérez 1976; García Marín 1987; Blázquez 2010; Carvajal, Añíbarro, Vítores 2012; Salazar 2000. 
Castilla tomando como referencia fundamental y como ángulo visual de acercamiento el seguimiento de los hermanos Mújica. Por ello este trabajo de investigación, pese a ser un estudio que tiene en cuenta las estructuras familiares de los Mújica, es al mismo tiempo un estudio indirecto sobre la Corte castellana y sobre las actividades políticas impulsadas en distintos momentos del reinado de los Reyes Católicos desde la Corte. Desde este planteamiento se pretende contribuir a un conocimiento más amplio de la complejidad de los procesos de centralización del poder regio y del desarrollo de la burocratización del reino en los distintos ámbitos de la administración castellana.

Por tanto, el punto de mira de la investigación se desarrolla a partir del estudio de las actuaciones políticas, diplomáticas, militares, económicas o financieras ${ }^{3}$ de cortesanos y servidores de los reyes Isabel y Fernando, los Mújica de Villafranca de Ordicia. Se examinará el tipo de comunicación producida entre los Mújica y los Reyes Católicos, porque dicha circunstancia podría indicarnos la existencia de lazos de patronaje entre los monarcas o algunos de sus más próximos colaboradores y cada uno de los miembros de dicha familia. Se persigue concretar las relaciones entre parentesco, poder y ascenso social, pues el parentesco y el enlace por vía matrimonial con otros núcleos familiares y linajes castellanos de prestancia han solido servir de palanca motriz de la promoción política y ascenso social de no pocas familias, como ha sido puesto de manifiesto en un número significativo de publicaciones ${ }^{4}$. Por este motivo se valorarán lógicamente las relaciones de parentesco forjadas por los Mújica, que no pueden desgajarse del clientelismo político adosado a las mismas, ni del intercambio de servicios resultante de dichos enlaces. El parentesco no es solamente una cuestión familiar, sino sobre todo una construcción social que irradia los más diversos ámbitos de la vida de los individuos ${ }^{5}$. La relación entre parentesco, poder y ascenso social sobresale de forma especial en el marco de las estructuras sociales medievales ${ }^{6}$. Ya hace 40 años, Jacques Heers, uno de los pioneros en el estudio de los grupos familiares medievales escribió que los lazos establecidos entre las familias se reforzaban mediante la solidaridad política y militar ${ }^{7}$. Política y familia son dos componentes destacados de

\footnotetext{
${ }^{3}$ En relación con la financiación de las guerras de la monarquía castellana remito al artículo de Ladero 2007, pp. 13-38.

${ }^{4}$ Beceiro, Córdoba de la Llave 1990; Dacosta 2003; Davis, Muller, Rees 2003; Díaz de Durana 2009; Gerbet 1994, 1997; Monsalvo 1993; Pardo de Guevara 1985; Beceiro 1995.

${ }^{5}$ Los estudios antropológicos sobre la familia están sirviendo a los historiadores para abrir el marco de comprensión de un fenómeno social con lecturas históricas complejas. Véase al respecto Goody 1983, que destaca de manera especial la importancia de la "familia cognaticia".

${ }^{6}$ Remito a Mattoso 1994 y a la obra de Duby 1988.

${ }^{7}$ Heers 1974, p. 14.
} 
los entramados de poder en la Edad Media. Conviene advertir si los lazos de parentesco establecidos por los Mújica pudieran estar detrás de la presencia de varios miembros de esta familia en la Corte, en un periodo caracterizado por un progresivo fortalecimiento del poder regio castellano y de sus instituciones públicas.

Opino que los datos que se poseen sobre la familia Mújica son de cierta relevancia en el plano histórico-político, no porque nos informan de sus actividades políticas, mercantiles, financieras y militares, lo que no dejaría de ser una cuestión privada, sino porque las mismas atañen directamente a las empresas de la monarquía castellana. La localización de sus testamentos e inventarios de bienes habría permitido recabar una información bastante completa en lo que concierne al plano individual de cada uno de los miembros de la familia Mújica, aunque son nombradas las familias de las que conocemos este tipo de fuentes documentales. Éste no ha sido, sin embargo, el propósito final del estudio, tal como se ha señalado previamente. Creo que la documentación conservada va a permitirnos ofrecer un bosquejo bastante preciso de los Mújica y de sus relaciones con la administración regia y sus diversas instituciones. Y sobre todo que conviene estudiarla con el propósito de conocer la funcionalidad socio-política de los Mújica, cuya acción política acaso pudo derivar de su proximidad al rey, a la Corte y a ese grupo reducido de personas donde se concretan finalmente las tomas de decisiones políticas y su puesta en ejecución.

Desde estos planteamientos las investigaciones históricas centradas en el análisis de la familia en sus más variadas vertientes se han convertido en una herramienta subsceptible de ser muy útil para comprender cómo se forjaron las organizaciones sociales que nos han precedido, tal como ha sido sostenido por Sebastián Molina y Antonio Irigoyen ${ }^{8}$. Asimismo, conviene que los historiadores se preocupen más por analizar y estudiar a los hidalgos no sólo como adláteres, clientes o vasallos de la nobleza titulada, sino también como un elemento activo, generador de sus propios intereses, en palabras de José Ramón Díaz de Durana y de otros historiadores ${ }^{9}$. En este sentido es preciso examinar el protagonismo que tuvieron los hidalgos cortesanos, es decir, aquellos que se implicaron en las actividades relacionadas con la Corte castellana y en la construcción de los estados de los reinos bajomedievales. Con frecuencia su relevancia en el plano político ha sido

\footnotetext{
${ }^{8}$ Molina, Irigoyen 2009, pp. 11-12.

${ }^{9}$ Díaz de Durana 2009; Gerbet 1997, pp. 67-69. Es ésta una de las vías de trabajo desarrolladas por el historiador Cos 1995. Conviene seguir insistiendo en estas hipótesis de investigación, pues las relaciones entre los hidalgos, los caballeros y los nobles titulados con las respectivas administraciones regias europeas fueron ciertamente complejas, Maczak 1996.
} 
minusvalorada, al haber sido considerados como simples clientes de la nobleza titulada. Y sin embargo, existieron hidalgos cortesanos que alcanzaron cotas de poder e influencia muy superiores a las que ejercieron no pocos caballeros asentados tradicionalmente en el entorno rural y menos frecuentemente en los centros urbanos. De hecho algunos hidalgos llegaron a ser miembros del Consejo Real, circunstancia que no se produjo a fines del XV en el caso de los Avendaño, los Butrón, los Rojas, los Hurtado de Mendoza -prestameros de Vizcaya- y de otros caballeros locales castellanos, señores de vasallos.

\section{BIOGRAFÍA DE LA FAMILIA MÚJICA Y ACTIVIDADES SOCIALES}

Ha solido ser más habitual que los historiadores hayan centrado sus investigaciones en los grandes linajes castellanos o en aquellos otros de menor rango que se codeaban con ellos al haber entrado en sus redes clientelares. Una de las causas de dicha circunstancia ha sido la conservación de una mayor documentación escrita por parte de estas familias y sus descendientes. La manera de enfrentarse con estos trabajos de investigación ha sido diversa. En el País Vasco contamos con publicaciones que de un lado ponen el énfasis en la evolución social de un determinado linaje ${ }^{10} \mathrm{y}$ de otro lado disponemos asimismo de aproximaciones generales que contemplan un conjunto de individuos de manera colectiva: la "alta nobleza" castellana o los "Parientes Mayores" solariegos ${ }^{11}$. En particular en lo que concierne a los "Parientes Mayores"12 se ha focalizado la atención en el examen de lo conflictos acaecidos entre los distintos grupos enfrentados y a veces se han descrito también los existentes en el seno de las propias familias ${ }^{13}$.

${ }^{10}$ García Fernández 2007a, 2007b, 2007c, 2008, 2009a; Munita et al. 2014.

${ }^{11}$ Díaz de Durana 1998, 2004.

${ }^{12}$ Los "Parientes Mayores" solariegos, normalmente los primogénitos varones, eran señores de solar-lugar donde a fines de la Edad Media levantaron sus casas torre-, patronos de iglesias de las que percibían sus diezmos e influían en el nombramiento de los clérigos, dueños de molinos o ferrerías, contaban con escuderos a su servicio y se asociaron regularmente en bandos y parcialidades de carácter político. Véanse a este respecto los estudios de Marín 1998 y Dacosta 1999.

${ }^{13}$ Cuestión que asimismo ha interesado a nivel general. Véase Aurell 2010. 


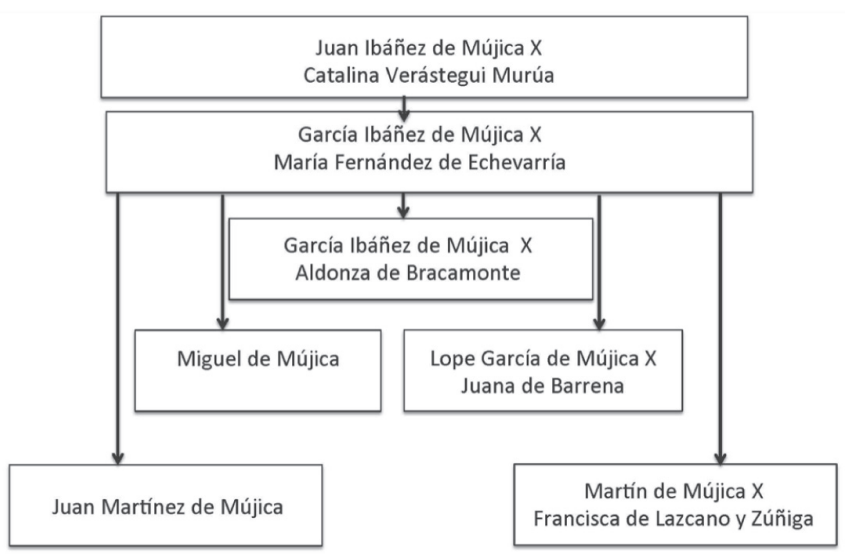

Cuadro 1. La familia Mújica de Villafranca de Ordicia en el siglo XV.

En esta ocasión el estudio se concreta en el examen de los miembros de la familia Mújica, sin duda alguna, gentes hidalgas, pero que ni pertenecieron a la "alta nobleza" castellana, ni al poderoso sector social de los caballeros que en los espacios alaveses, guipuzcoanos o vizcaínos fueron calificados asimismo por los dirigentes urbanos como "Parientes Mayores". Las clases gobernantes de las villas guipuzcoanas y de la Provincia crearon todo un discurso político que presenta a los "Parientes Mayores" en numerosos escritos, incluídas las ordenanzas de las Hermandades de Guipúzcoa, como sus principales enemigos para su afirmación y consolidación institucional en el territorio.

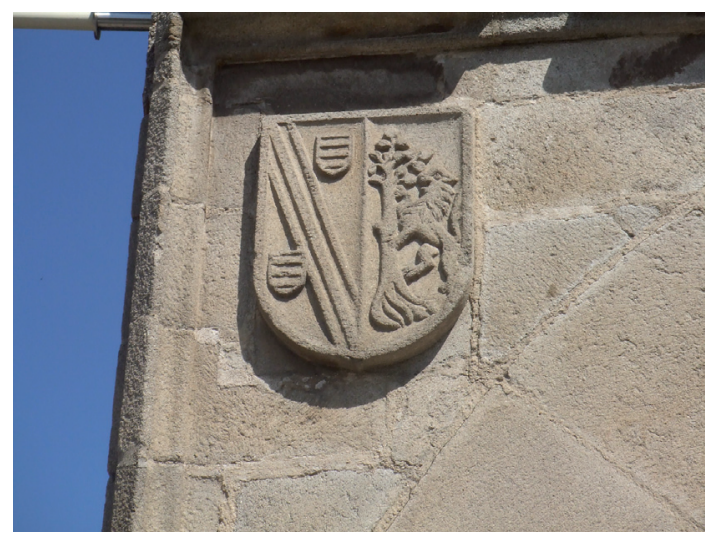

Fig. 1. Escudo de García Ibáñez de Mújica, miembro del Consejo Real, en la fachada del Palacio de la Diputación Provincial de Ávila. 
Las personas analizadas de la familia Mújica son las siguientes: García Ibáñez de Mújica, el padre, y los hijos Lope García de Mújica, Martín de Mújica, Miguel de Mújica, Juan Martínez de Mújica y García Ibáñez de Mújica. La residencia habitual del padre fue una de las escasas casas torres que se levantaron en la localidad de Villafranca de Ordicia. Serapio Múgica escribió que la casa torre de los Mújica estaba ubicada junto a la iglesia de la localidad y añadió que a fines de 1897 se instruían en ella los niños de la villa ${ }^{14}$. El primer signo de identidad de la familia en las fuentes escritas es el apellido Mújica. Además, como otras familias hidalgas castellanas, disponía de una heráldica propia y su estilo de vida predominante era el de los caballeros ${ }^{15}$. Las armerías de los Mújica en su mitad izquierda del escudo se caracterizan por contar con una banda terciada en dos escudetes fajados de tres fajas. En la mitad derecha se representa a un león rampante al tronco de un árbol verde. El toponímico Mújica, la casa torre donde tienen su ascendencia y los emblemas del escudo del grupo son elementos identitarios concebidos al servicio de la cohesión interna de la familia.

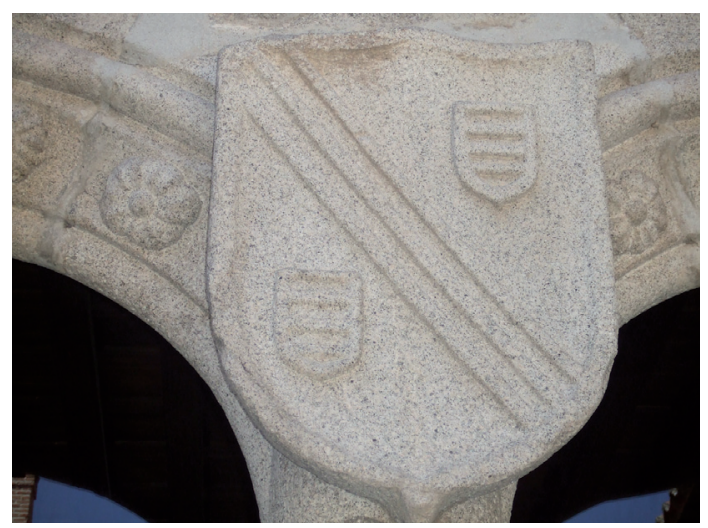

Fig. 2. Uno de los emblemas del escudo de García Ibáñez de Mújica, miembro del Consejo Real, en el palacio por él construido en Ávila.

Los seis Mújicas examinados fueron naturales de la villa guipuzcoana señalada, si bien la localidad se les quedó pequeña desde el punto de vista de su progresión social y patrimonial. No es improbable que los Mújica guipuz-

\footnotetext{
14 "Los niños adquieren la instrucción primaria en dos escuelas nacionales y una municipal completas, muy bien instaladas desde fines del año 1897 en la antigua casa-torre de Muxica"; Múgica 1918b.

${ }^{15}$ En relación con el estilo de vida de la nobleza castellana remito a las observaciones de Gerbet 1994,pp. 225-231.
} 
coanos fueran una rama familiar descendiente del poderoso linaje de la Casa solariega de los Mújica del Señorío de Vizcaya ${ }^{16}$. En cualquier caso los Mújica guipuzcoanos estaban bastante bien insertados desde mediados del siglo XV en el "cuerpo" de las elites sociales y económicas de dicha villa y de la Provincia de Guipúzcoa, institución que consiguió convertirse en la principal interlocutora política de los vecinos y pobladores de este territorio con la monarquía castellana ${ }^{17}$. Ciertamente la participación política de las elites locales en los gobiernos urbanos y en su caso en los provinciales, no es algo novedoso, sino que fue consubstancial en la mayoría de las ciudades y villas castellanas ${ }^{18}$.

Este escenario sociopolítico fue el punto de partida del posterior encumbramiento socio-político de los Mújica en el marco espacial de la Corte de la Corona de Castilla.

\subsection{El padre}

García Ibáñez de Mújica, el padre ${ }^{19}$, casado con María Fernández de Echevarría, desempeñó diversos cargos municipales en su localidad de origen entre mediados y finales del siglo XV, siendo alcalde de la villa en $1488^{20}$. Aunque sobresale en el plano político por ser uno de los líderes de las villas guipuzcoanas que en 1456 resultaron desafiados a un reto por Juan López de Lazcano, Martín Ruiz de Gamboa y Ladrón de Balda, "Parientes Mayores" solariegos, que no estuvieron dispuestos a aceptar que los dirigentes de los núcleos urbanos se constituyeran en una hermandad y formaran ligas políticas contra los caballeros de solar. Los "Parientes Mayores" echaron la culpa a los dirigentes de una serie de villas de Guipúzcoa del derribo de sus casas torres y de haberles puesto mal contra el rey ${ }^{21}$. De otro lado sabemos que García Ibáñez de Mújica fue uno de los testigos que intervino en la investigación llevada a cabo en la Provincia de Guipúzcoa por Bartolomé de Zuloaga, pesquisidor enviado por los Reyes Católicos para examinar las mercedes que

${ }^{16}$ Sus orígenes se hallan en Mújica (Busturia-Vizcaya) de donde se extendieron a Villafranca de Ordicia, Idiazábal, Gudugarreta y Goiatz. La mayoría de los autores resaltan su ascendencia del linaje de la Casa Mújica-Butrón, véase Estornés (Fondo): http://www.euskomedia.org/ aunamendi/77595\#6 [consulta: 02/01/14].

${ }^{17}$ Lema et al. 2002.

${ }^{18}$ Véase el ejemplo de Paredes de Nava estudiado por Muñoz 2009.

${ }^{19}$ Los padres del escribano García Ibáñez de Mújica fueron Juan Ibáñez de Mújica y Catalina Verástegui Murúa, según Guerra 1908-1912.

${ }^{20}$ Fue bolsero del concejo de Villafranca de Ordicia en 1451, regidor en 1492, procurador en 1495, así como escribano en 1481 y 1495: Aragón 2012b, p. 322. En 1452 es designado por el concejo procurador para el seguimiento de pleitos: Ayerbe, San Miguel 2013, núm. 31.

${ }^{21}$ Arocena 1981, p. 109. 
Enrique IV había concedido en el Reino desde el mes de septiembre de 1464 hasta la celebración de las Cortes de Toledo en 1480, varios años después de la llegada al trono de los Reyes Católicos.

\subsection{Los hijos: Martín, Miguel, Juan y García}

Martín de Mújica fue maestresala de la reina Isabel de Castilla y a su muerte de la reina Juana, comendador de la orden militar de Santiago en Villamayor y contador mayor de cuentas a principios del siglo XVI ${ }^{22}$. Martín de Mújica contrajo matrimonio a fines del XV con Francisca de Lazcano y fundó mayorazgo en Villafranca de Ordicia el año 1515 a favor de su hijo Martín de Mújica y Lazcano, que casó con María de Guevara ${ }^{23}$, nieta del comendador de la orden militar de Santiago don Nicolás de Guevara, vecino de la villa de Segura en Guipúzcoa. Los Mújica, por tanto, aparecen entre el grupo del reducido número de familias que en los años finales de la Edad Media conformaron mayorazgos individualizados autorizados expresamente por los reyes en los territorios de Álava, Guipúzcoa y Vizcaya ${ }^{24}$.

En 1500 Martín de Mújica es el receptor de la artillería recogida por el bilbaíno Juan de Arbolancha, con quien colaboró su hermano Lope de Mújica, a los maestres de naos y a otras personas que se embarcaron en la armada de la archiduquesa que se dirigió a Flandes. Martín de Mújica la depositó en Málaga en manos del mayordomo de la artillería real, don Rodrigo de Narváez, el 4 de julio de dicho año ${ }^{25}$.

La estrecha colaboración de Martín de Mújica con Fernando el Católico le trajo algunos inconvenientes personales con Felipe el Hermoso, marido de la reina Juana, hija de Fernando. Martín de Mújica llegó a informar sobre cuál era la situación mental de Juana a su padre Fernando antes que a Felipe, su marido. Éste parece ser el motivo de las desavenencias surgidas entre Martín y Felipe el Hermoso. En este contexto político Fernando el Católico

\footnotetext{
${ }^{22}$ Algunos autores han señalado que fue miembro del Consejo Real y gobernador de Chile, datos que es necesario confirmar. A mediados del XVII se documenta un gobernador en Chile llamado Martín de Mújica y Butrón, natural de Villafranca.

${ }^{23}$ Padres de María de Guevara fueron Juan Vélez de Guevara e Inés de Albornoz.

${ }^{24}$ En el condado de Oñate en 1477 el conde Iñigo de Guevara dio permiso a los hidalgos para que pudieran hacer mayorazgo, reservando la legítima al resto de los herederos. Véase García Fernández 2004, p. 309. El sistema de mayorazgo con el consentimiento expreso de los reyes tardó igualmente en implantarse en el reino de Galicia, siendo muy pocas las familias que contaron con estos instrumentos notariales. Véase Framiñán, Presedo 2005, p. 121.

${ }^{25}$ Véase Ladero 2003, p. 106.
} 
decidió enviarle como embajador a Londres ${ }^{26}$. En 1510 Martín de Mújica ya aparece firmando como lugarteniente de contador mayor de cuentas los finiquitos del pedido y de las alcabalas de la ciudad de Vitoria emitidos por la Contaduría Mayor de Cuentas ${ }^{27}$.

El “vizcaíno" Miguel de Mújica ${ }^{28}$ tuvo una proyección política en otros territorios de la Corona de Castilla. Participó en la conquista de Gran Canaria a partir de 1481, donde aparece citado en un primer momento como "receptor de los quintos reales", siendo el encargado de controlar que los repartimientos se hicieran a favor de soldados que hubieran participado personalmente en la ocupación, control y dominio de la isla. A lo largo del año 1481 el gobernador Pedro de Vera encomendó a Miguel de Mújica que llevara a la Península Ibérica a presencia de los Reyes Católicos al "guanarteme" canario de Gáldar que había sido presuntamente capturado en Agaete por las fuerzas militares de Alonso Fernández de Lugo. Este cometido tuvo efecto en Calatayud (Aragón).

Existe información precisa sobre Miguel de Mújica en las cuentas de la conquista de Gran Canaria publicadas por Miguel Ángel Ladero Quesada. Estas cuentas fueron elaboradas entre 1481 y 1482 por Pedro de Arévalo, proveedor del ejército castellano enviado a la isla al mando del gobernador Pedro de Vera y de Miguel de Mújica. Pedro de Arévalo presentó a los Contadores Mayores de Cuentas las cartas de pago firmadas por Pedro de Vera y Miguel de Mújica, mediante las que justificó sus actuaciones como proveedor ${ }^{29}$.

Finalmente Miguel de Mújica falleció en Gran Canaria en los combates que se produjeron con la población indígena en Ajodar, donde conjuntamente con un grupo de "vizcaínos" que le acompañaron en el segundo viaje que hizo a Gran Canaria iniciado en el Puerto de Santa María (Cádiz) en octubre de 1482, fue hasta su muerte uno de los baluartes de las fuerzas militares castellanas comandadas por el gobernador Pedro de Vera ${ }^{30}$. Precisamente, entre 1481 y 1482, Miguel de Mújica ya figura en la documentación de la Conta-

\footnotetext{
${ }^{26}$ Rodríguez Muñoz 1951, p. 126.

${ }^{27}$ García Fernández 2010b, p. 113.

${ }^{28}$ Fue calificado como vizcaíno en algunas fuentes escritas, pese a ser guipuzcoano, sin duda por hablar también el vascuence. En la Edad Media con frecuencia a quienes hablaban vascuence les denominaban vizcaínos.

${ }^{29}$ En las mismas se anotan los mantenimientos recibidos por Miguel de Mújica en los dos viajes documentados que realizó a Gran Canaria para las huestes castellanas y para levantar las fortificaciones necesarias (armas, plomo, cereales, pólvora, alimentos diversos, cueros y dinero). En el primero de los viajes fue en la carabela Gaeta. En el segundo viaje llevado a cabo en octubre de 1482, además de hierro, armas, pólvora, 4 ruedas para molino y cereal recibió del proveedor la suma de 362.200 maravedíes. Se fletaron desde el Puerto de Santa María la nao "Sevillana" y la carabela "Papagayo". Y previamente Miguel de Mújica se ocupó de recibir abastecimientos cerealísticos en la ciudad de Sevilla, Ladero 1966, pp. 41-57.

${ }^{30}$ Además de vizcaínos otras gentes de Castilla se sumaron a la conquista de Gran Canaria bajo la dirección de Miguel de Mújica: Rosa 1963; Cabello 1977; Lobo 2012. Hubo otra perso-
} 
duría Mayor de Cuentas del Archivo General de Simancas como beneficiario de un juro de heredad en las alcabalas de la Merindad de Allende Ebro.

Por otra parte contamos con otra noticia de particular interés, que nos ayuda a conocer mejor la proyección política alcanzada por Miguel de Mújica en la conquista de Gran Canaria. Ésta tiene que ver con la formación y el aprendizaje adquiridos por Miguel de Mújica durante el tiempo que fue criado de Rodrigo de Ulloa. Rodrigo de Ulloa, hijo del doctor Periáñez, fue contador mayor de los Reyes Católicos, comendador de la orden militar de Santiago en el valle de Ricote, señor de la Mota del Marqués (Valladolid) y alcaide de las fortalezas de Toro y Almuñécar, así como partidario de Isabel la Católica en las disputas que se ocasionaron en relación con el acceso al trono de esta última. El servicio de Miguel de Mújica a Rodrigo de Ulloa, con quien debió aprender y formarse en cuestiones relacionadas con la gestión administrativa, debió ser uno de los resortes fundamentales que le propulsaron a participar en esa gran empresa que fue la conquista de Gran Canaria ${ }^{31}$. No se sabe cómo llegó a ser criado del contador, pero probablemente esta circunstancia fue una consecuencia de las estrategias de la familia Mújica por impulsar y promocionar a sus componentes. Dicho de otra manera, si el contador se fijó en Miguel para que fuera su criado pudo deberse asimismo al interés de la familia Mújica porque aprendiera un oficio junto a una persona de la relevancia de Rodrigo de Ulloa ${ }^{32}$.

Juan Martínez de Mújica, fue otro de los hijos del escribano García Ibáñez de Mújica. En 1491 estuvo presente en las campañas de la guerra de Granada $^{33}$. Y aparece citado como teniente de fiel de la villa de Villafranca de Ordicia en 1499 y como bolsero de la localidad en 1478, 1497, 1499 y $1507^{34}$. Juan Martínez de Mújica, a través del oficio de bolsero, controlaba las finanzas municipales de dicha población y su reiteración en el cargo durante 4 años denota la confianza depositada en él por los miembros del concejo de la localidad.

Está documentado que fue uno de los pecheros enteros de Villafranca de Ordicia para el pago de la "foguera provincial" en 1506. Las Hermandades de Guipúzcoa repartían los maravedíes que necesitaban para financiar

na con el mismo nombre, hijo o pariente, que es citado en una relación de vecinos de Villafranca de Ordicia: Ayerbe, San Miguel 2013, núm. 47.

${ }^{31}$ Rodrigo de Ulloa falleció en 1494: Rodríguez, Malpica 1982. Sobre la familia Ulloa y sus relaciones con Villena remito a Moreno, Franco 1990-1991, pp. 115-116.

${ }^{32}$ Hay otro caso en Villafranca de familias cuyos hijos fueron criados de miembros de la Corte. Juan de Arteaga, hijo del escribano Juan Íñiguez de Arteaga, fue criado del secretario de Fernando el Católico, Fernando de Zafra, y accedió a una escribanía pública de la villa en 1489: AGS, RGS, 1489, 356.

${ }^{33}$ García Fernández 2009b, p. 336.

${ }^{34}$ ARChV, Pleitos Civiles, 1295-1. Véase Aragón 2011. 
los cometidos aprobados en las Juntas Generales entre los diferentes núcleos urbanos que las formaban. Cada población había sido fijada en un determinado número de "fogueras" o de "fuegos". Así que la cantidad solicitada por las Juntas Generales se distribuía entre el número de fogueras. A su vez en cada localidad el número de "fogueras" asignado se pagaba teniendo en cuenta la capacidad económica de los vecinos. Como "pechero entero" era uno de los vecinos que más contribuía al pago de los repartimientos provinciales, lo que quiere decir que Juan Martínez de Mújica formaba parte del reducido número de vecinos con mayor patrimonio y riqueza de la población.

Asimismo el concejo de la villa de Villafranca de Ordicia le designó procurador para negociar el encabezamiento perpetuo de las alcabalas de la Provincia de Guipúzcoa con la administración regia en $1508^{35}$. La consecución del encabezamiento perpetuo de alcabalas fue uno de los grandes logros de las Hermandades Generales de la Provincia de Guipúzcoa, añorado y reivindicado vanamente por los dirigentes de las Hermandades de la contigua Provincia de Álava, que debieron conformarse con que cada población renegociara periódicamente el montante total de los encabezamientos de alcabalas con los representantes de la Corte ${ }^{36}$. Esto mismo sucedía en el resto de la Corona de Castilla. Serapio Múgica y Álvaro Aragón han sostenido que llegó a ser nombrado maestresala de la princesa doña Juana.

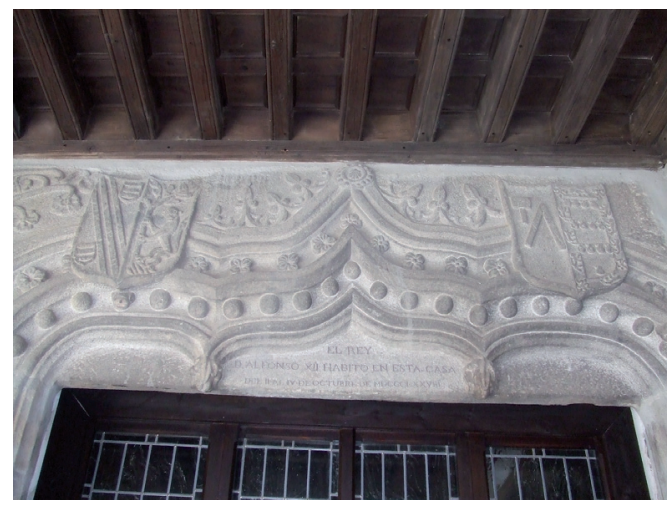

Fig. 3. Escudos de los Mújica (a la izquierda) y Bracamonte (a la derecha), en el palacio renacentista de la Diputación de Ávila.

${ }^{35}$ Goicolea, García 2012, pp. 256 y 264.

36 Álava no consiguió el encabezamiento perpetuo de alcabalas hasta el 12 de agosto de 1687. En 1529 el alcalde de Vitoria se dirigió a la Corte con 4.000 ducados (1.500.000 maravedíes) con el propósito de comprar dicho derecho. Había expectativas entre los gobernantes de conseguir el encabezamiento perpetuo de alcabalas para la ciudad, pero quedaron finalmente frustradas: García Fernández 2012a, p. 19. 
Para terminar con este punto me voy a referir al licenciado García Ibáñez de Mújica. Serapio Múgica -que sigue de forma bastante disciplinada los escritos del cronista de Felipe II don Esteban de Garibay- ha escrito que Lope García de Mújica era hermano de Martín de Mújica y de García Ibáñez de Mújica. Al respecto afirma que este último personaje fue licenciado por la Universidad de Salamanca -en cuya ciudad residió en el Colegio Mayor de San Bartolomé-, oidor del Consejo Real y de Cámara de los Reyes Católicos y de la reina Juana y fundador del mayorazgo de los Mújica en Ávila antes de fallecer en $1520^{37}$. Nos encontraríamos, por tanto, con la fundación de un nuevo mayorazgo por otro miembro de la familia Mújica.

Es reseñable que el licenciado García Ibáñez de Mújica, pese a no formar parte de los tradicionales linajes solariegos guipuzcoanos, vizcaínos o alaveses, se llame de igual manera que su padre, al contar con el mismo antropónimo, patronímico y toponímico, alusivo este último al lugar de origen o al solar de procedencia. De este modo se persigue reforzar el papel del primogénito, afirmar la posición jerárquica del mismo en el seno de la familia y perpetuar la memoria genealógica del antecesor del que se toman dichos distintivos de identificación ${ }^{38}$.

Las más recientes investigaciones históricas centradas en la Corte de Castilla certifican que en 1498 se produjo una reforma de la administración que desembocó en la incorporación de nuevos consejeros. De este modo Martín Fernández Angulo, García Ibáñez de Mújica y Luis Zapata, antiguos consejeros del Príncipe Juan, accedieron a uno de los principales organismos de la Corona de Castilla, el Consejo Real ${ }^{39}$.

\footnotetext{
${ }^{37}$ No dice nada, sin embargo, de quién era el padre de estos hermanos, llamado igualmente García Ibáñez de Mújica: Múgica 1918a, 1918b; Galdos 2008; Gorosábel 1862 , p. 620 .

${ }^{38}$ Véase Pardo de Guevara 2012.

${ }^{39}$ Fernández de Córdova 2004. Esta reforma se justificó a causa de las denuncias existentes por malversaciones fiscales y para reducir el peso de los judeoconversos en la Corte. Fernán Álvarez y Juan de la Parra que gestionaban el Real patronato de Granada y el doctor Rodrigo Maldonado de Talavera, consejero, fueron sustituidos. Véase también Fernández de Córdova 2002. Gonzalo Fernández de Oviedo recoge entre los miembros del Consejo de la Casa del Príncipe Juan al licenciado Zapata, al licenciado Mújica y al doctor Martín, las tres personas incorporadas al Consejo de los Reyes Católicos: Fernández de Oviedo 2006.
} 


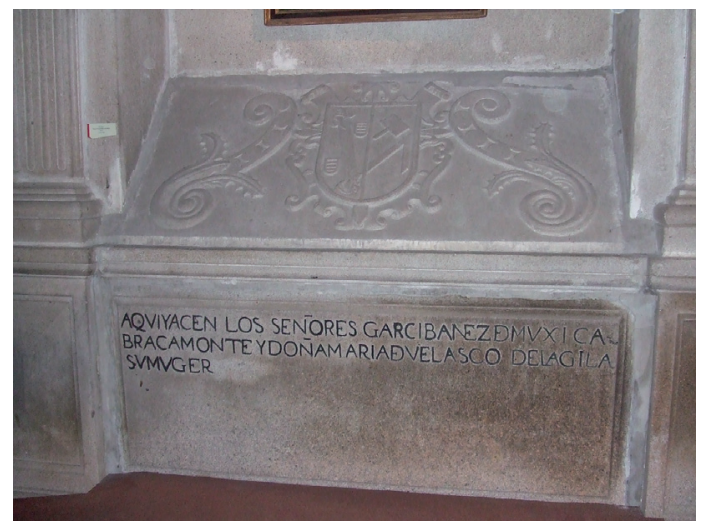

Fig. 4. Tumba de García Ibáñez de Mújica y Bracamonte, descendiente de

García Ibáñez de Mújica, miembro del Consejo Real de Castilla, ubicado en la capilla del Cardenal de la catedral de Ávila.

Su escudo es visible en la tapa del sepulcro.

En relación con el ascenso tan fulgurante del licenciado García Ibáñez de Mújica a las más altas instancias del poder regio es necesario tener en cuenta los esponsales realizados en Ávila. García Ibáñez de Mújica se asentó en la ciudad de Ávila donde contrajo matrimonio con Aldonza de Bracamonte, hija de Juan de Bracamonte, señor de Fuente el Sol (Valladolid) y de Teresa de Vargas, vecina de Ávila ${ }^{40}$.

Para comprender la relevancia del linaje Bracamonte conviene poner sobre la palestra dos noticias. La primera que la mujer de García Ibáñez de Mújica fue nieta del mariscal de Castilla, Álvaro Dávila -miembro de una de las familias más poderosas de Ávila- y de Juana de Bracamonte -hija del almirante francés mosén Rubí de Bracamonte (Robert de Braquemont)-. Y la segunda que los hijos de Álvaro adoptaron como apellido principal el de Bracamonte en lugar de Dávila. De este modo el licenciado García Ibáñez de Mújica, sumó a su elevada formación cultural y profe-

${ }^{40} \mathrm{ARChV}, \mathrm{RE}, 400 / 52$. Hoy en día la torre y palacio de los Mújica (o de los Guzmanes) es la sede de la Diputación Provincial de Avila. García Ibáñez comenzó a levantar dicho edificio sobre otro anterior a principios del siglo XVI. Aún es visible el escudo de los Mújica en el palacio, el mismo que utilizó la familia en la villa de Villafranca, Estornés (Fondo): http://www.euskomedia.org/aunamendi/126194/96542 [consulta: 02/01/14]. Véanse Franco 1986-1987; Parrado 1981; Cascales 1775. El padre de Aldonza dispuso de un juro de heredad sobre la villa de Santander. Aldonza tuvo tres hijos con García Ibáñez de Mújica: Aldonza, Antonio y Francisca. El nombre Aldonza recuerda a Aldonza de Ayala, mujer de Pedro González de Mendoza, cuya hija Inés de Mendoza se casó con el almirante Rubí de Bracamonte. 
sional, los apoyos de su familia guipuzcoana y teóricamente los del influyente linaje avulense al que se había incorporado al casarse con Aldonza. La unión matrimonial de Aldonza con García Ibáñez de Mújica supuso la entrada en la "casa y patronazgo" del linaje Bracamonte, que como sucedió en otros casos de Castilla, amparó a los "segundones" o a los maridos de quienes se habían aupado al carro de la estirpe familiar mediante los correspondientes casamientos ${ }^{41}$.

Aquí se encuentra el contexto familiar, social y político del ascenso político-administrativo del licenciado García Ibáñez de Mújica a la Corte, lo que le generó prestigio, poder y beneficios económicos substanciosos. Aunque es sabido que una parte de la fortuna de García Ibáñez de Mújica provino de rentas situadas en las Islas Canarias, donde había encontrado la muerte su hermano Miguel de Mújica, junto con otros lacayos suyos.

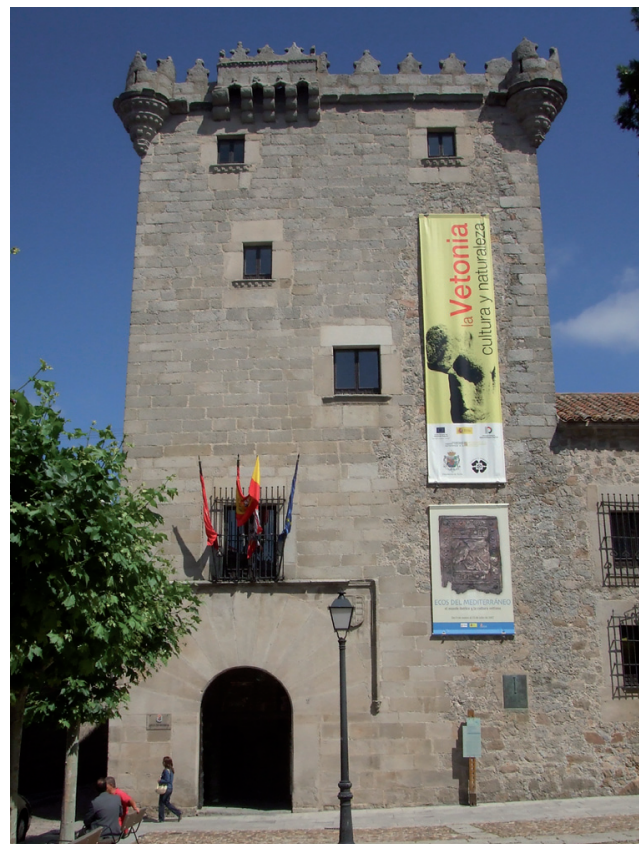

Fig. 5. Torreón de los Mújica en Ávila, construido por García Ibáñez de Mújica, miembro del Consejo Real.

${ }^{41}$ Casey, Hernández 1997. 


\subsection{Lope García de Mújica}

Ni los archivos locales, ni la documentación de los Archivos Generales del Estado descuidan la figura de Lope. Se sabe que estaba casado con doña Juana de Barrena ${ }^{42}$. Las fuentes locales también aluden ocasionalmente a este personaje, cuyas caserías, ubicadas en los términos de Villafranca, eran explotadas por caseros o arrendatarios campesinos que debían entregarle unas rentas anuales. En el padrón fiscal de Villafranca de Ordicia realizado en 1506 para pagar la "foguera provincial" y el pecho de Santa María de Agosto, un tributo al que estaban obligados también los hidalgos de las villas y collaciones que formaban parte de las Hermandades de la Provincia de Guipúzcoa, es alineado en la primera posición del grupo de los "pecheros enteros" 43 . Este dato ya nos está indicando la primacía que se le otorgaba en la localidad. Álvaro Aragón, en un artículo reciente, ha señalado que Lope García de Mújica, “contino" de los Reyes Católicos, fue maestresala de la reina Juana y teniente de alcaide de Fuenterrabía en 1506. Probablemente no es fortuito que este mismo año Martín de Mújica, su hermano, sustituyera a Hurtado de Luna, alcaide en dicha fortaleza desde unos años antes ${ }^{44}$.

El Archivo General de Simancas recoge información sobre algunas de las rentas de origen regio que disfrutó, como compensación por las misiones que cumplió sirviendo los intereses de la monarquía castellana. En 1495, Lope de Mújica percibía un juro de heredad de 5.000 maravedíes en las alcabalas de la villa de Tolosa de la Merindad de Allende Ebro. De este situado seguía siendo beneficiario a principios del siglo XVI. Documentación correspondiente al año 1502 nos revela que los Reyes Católicos le habían emitido la carta de merced de los 5.000 maravedíes en la ciudad de Sevilla el 16 de diciembre de 1484. Esta cantidad provenía de la renuncia que hizo doña Guiomar de Castro, duquesa de Nájera, a cobrar 20.000 maravedíes de juro de heredad que Enrique IV le había otorgado por los servicios prestados en las alcabalas de la villa guipuzcoana de Tolosa. Aunque parece claro que se trata del traspaso del juro de heredad que anteriormente había disfrutado su hermano Miguel.

Tras el fallecimiento de su hermano Miguel en 1483 en las luchas acaecidas en Gran Canaria entre las gentes de Castilla que se dirigieron allí a controlar la región y la comunidad indígena, recibió otras rentas de mayor cuantía generadas en los derechos del diezmo viejo del hierro y acero, que entraba y salía de la villa de Tolosa, procedente de las ferrerías navarras de

\footnotetext{
${ }^{42}$ Ayerbe, San Miguel 2013, núm. 45.

${ }^{43}$ Goicolea, García 2012, p. 256.

${ }^{44}$ Aragón 2012a, pp. 265-266. Según Serapio Mújica en 1505 se encontraba en la región de Flandes.
} 
Leiza, Areso y Araiz, así como de la ferrería de Ballinas, ubicada en el valle de Leizarán, dedicada a la producción de cobre. Lope contaba igualmente con un juro situado en una ferrería construida a principios de la década de los 80 del siglo XV por los concejos de Villabona y Amasa en los montes "Dezquibia y Ayroa". Lope de Mújica en los años finales del siglo XV tenía una serie de rentas que la Corona le pagaba a partir de los ingresos obtenidos por el rey en la Merindad de Allende Ebro en concepto del tributo de las alcabalas en forma de juros de heredad (renta perpetua) o cartas vizcaínas (renta vitalicia) ${ }^{45}$ y asimismo ingresó otras cantidades económicas provenientes de los derechos de las ferrerías de la monarquía en Guipúzcoa ${ }^{46}$.

También por estos años de finales del siglo XV los Reyes Católicos concedieron otros 50.000 maravedíes a Lope García de Mújica para ayuda de las costas de su viaje a Bretaña. Probablemente esta elevada cifra está relacionada con la flota militar que la monarquía castellana envió en ayuda del Duque de Bretaña. Al mando de esta armada se puso a Diego Gómez Sarmiento, Conde de Salinas (Álava). A tal efecto, para sufragar dicha empresa, se ordenó a Lope Martínez de Zarauz, escribano de las rentas regias en la Merindad de Allende Ebro, la preparación y recaudación de un repartimiento sobre las rentas de las ferrerías de Guipúzcoa ${ }^{47}$.

Los Reyes Católicos, Isabel y Fernando, encargaron en 1486 a Lope de Mújica la adquisición de una serie de armas en Álava, Guipúzcoa y Vizcaya. Con este propósito Pedro González de Frómista, tesorero de la Bula de Cruzada en el Condado de Vizcaya, entregó a Lope de Mújica una suma de 400.000 maravedíes con la finalidad de que con ellos comprara armas ofensivas y defensivas. A tal efecto los Reyes Católicos emitieron a su favor una carta de libramiento fechada el 7 de septiembre de 1486. Este armamento habría de ser utilizado en la guerra que los reyes castellanos mantenían con los moros granadinos. El propio Lope de Mújica, actuando como agente comercial de la monarquía, transportó las armas hasta la villa de Écija donde las entregó al mayordomo de artillería Juan de la Parra, secretario de sus altezas ${ }^{48}$.

Unos años más tarde, entre 1496 y 1497, los Reyes Católicos enviaron a Lope de Mújica, como uno de sus hombres de confianza, al Señorío de Vizcaya y a la Provincia de Guipúzcoa para movilizar la armada que se pre-

\footnotetext{
${ }^{45}$ García Fernández 2013.

${ }^{46}$ En relación con el número de ferrerías de Guipúzcoa y de Vizcaya, sus características e ingresos que generaban a la hacienda regia remito a Díez de Salazar 1997; Dacosta 1997; Urteaga 1996.

${ }^{47}$ AGS, Consejo de Hacienda, legajo 891.

${ }^{48}$ AGS, CMC, 1a época, legajo 97.
} 
paraba con destino a Flandes en los puertos cantábricos ${ }^{49}$. Era un hombre de la tierra y como tal podía conocer las preocupaciones políticas y tributarias de guipuzcoanos y vizcaínos, muy celosos, según el cronista Fernando del Pulgar, de que sus privilegios y libertades no fueran vulnerados por las nuevas exigencias de la monarquía y de sus oficiales ${ }^{50}$.

En este sentido merece la pena recordar de forma sumaria algunos acontecimientos acaecidos unos años antes en las provincias costeras de Vizcaya y Guipúzcoa, en concreto entre 1481 y 1494. En 1481 ya hubo quejas de vizcainos y guipuzcoanos ante las demandas de la Corona para formar una flota con la que se quería combatir a los turcos asentados en el ocupado Otranto ${ }^{51}$. Y en 1484 las Hermandades de la Provincia de Guipúzcoa reclamaron una disminución de las demandas de hombres armados y de naves solicitadas por la Corona en su lucha con el Islam. Y se entabló una negociación política en toda regla entre los representantes de la Provincia y de la administración regia ${ }^{52}$.

Unos años después, en 1493, se produjeron alborotos en las Encartaciones de Vizcaya, comarca donde hubo quienes se negaron a contribuir al empréstito de 333.000 maravedíes que les correspondía de los 2.000 .000 que cupo al Señorío de Vizcaya para los preparativos de una nueva armada, según István Szászdi León-Borja ${ }^{53}$. En 1493 los Reyes Católicos habían encargado a Alonso de Quintanilla, contador mayor de cuentas, y al doctor Villalón la preparación de una armada en Vizcaya ${ }^{54}$. $\mathrm{Al}$ respecto se generó un pleito entre Sancho Ortiz de Aedo, alcalde del concejo de Zalla y Antonio Cornejo, corregidor de Vizcaya. Entre quienes se resistieron en las Encartaciones al pago de dicho préstamo se encontraba el preboste de Portugalete, Ochoa de Sala$z^{5}{ }^{55}$. Igualmente hubo oposición y obstrucción a que se iniciara el proceso

\footnotetext{
${ }^{49}$ Ladero 2003, pp. 18 y 31. La contribución de los marinos vascos a las armadas castellanas fue relevante: Ladero 2001; Pérez de Tudela 1973.

50 "Los moradores de aquellas tierras son gente sospechosa, y algunos de ellos porque no les daban cargo, otros porque no eran recibidos sus votos, otros porque no se contentaban con los gages y sueldos que les daban, y otros porque no querían dar sus naves para la armada, ponían empacho e impedían que se hiciese, diciendo ser contra sus privilegios y contra sus grandes libertades, de que los de aquella tierra gozan y les fueron guardadas por los reyes de España, antecesores del rey e de la reina. Y sobre esto ponían turbaciones e impedimentos de tan mala calidad, que todas aquellas gentes se escandalizaron diciendo que sus privilegios y libertades eran quebrantadas (...) que aquellos comisarios venían a los engañar y quebrantar sus privilegios, y a los hacer pecheros y tributarios". Véase Pulgar 1943, cap. CXIX.

${ }^{51}$ Ladero 2003, p. 38

${ }^{52}$ García Fernández 2010a.

${ }^{53}$ Szászdi 1999.

${ }^{54}$ ARChV, RE, Legajo 104/13.

${ }^{55}$ Ochoa de Salazar, señor de San Martín de Muñatones y su pariente Ochoa de Salazar, preboste de Portugalete, fueron apresados en 1493 por orden de Alonso de Quintanilla y del doctor Villalón debido a la resistencia señalada. AGS, RGS, legajo 1494, 09, 138.
} 
de recaudación de este empréstito en las colindantes tierras alavesas de Ayala, Arrastaria y Urcabustaiz. Su procurador, Sancho García de Murga, señor de la Casa de Murga y uno de los principales "Parientes Mayores" de la Tierra de Ayala ${ }^{56}$, defendió públicamente la exención del pago de cualquier tipo de demandas y más concretamente de dicho préstamo, alegando que, de acuerdo con sus derechos y libertades, estaban exentos de este tipo de contribuciones ${ }^{57}$.

Datos contables conservados en el Archivo General de Simancas constatan que el empréstito solicitado por la Corona con el objetivo de preparar una armada en los puertos de Vizcaya fue bastante elevado. A los mercaderes de Burgos se les reclamó 1.864 .968 maravedíes, a las 4 villas de la Costa -San Vicente de la Barquera, Santander, Laredo y Castro Urdiales- 264.997 maravedíes, a la ciudad de Logroño 200.000 maravedíes, a Vitoria y Álava 335.050 maravedíes, a la Provincia de Guipúzcoa 1.200.000 maravedíes y a Vizcaya, sin las Encartaciones, 1.666 .670 maravedíes $^{58}$.

En este marco de referencia se produjo la designación en 1496 de Lope de Mújica y de Carlos Enríquez de Cisneros, corregidor de las Cuatro Villas de la Costa, como encargados de distribuir las armas entregadas a cada maestre de nao y a otras personas particulares ${ }^{59}$. $\mathrm{Al}$ año siguiente concedieron a Lope una carta de libramiento de 20.000 maravedíes en concepto de quitación por "contino" de sus majestades ${ }^{60}$, cantidad que seguía disfrutando anualmente a principios del siglo XVI, tal como se recoge en las cuentas de los tesoreros del distrito fiscal de la Merindad de Allende Ebro ${ }^{61}$.

Lope García de Mújica aparece citado igualmente como receptor y distribuidor de sumas de dinero considerables entre las tropas castellanas de don Fadrique Enríquez, almirante de la mar de Castilla ${ }^{62}$. Lope de Mújica, en febrero de 1497, le adelantó la elevada suma de un millón de maravedíes, como anticipo para pagar a los hombres de guerra que estaban bajo sus órdenes, más otra cantidad de 525.000 maravedíes destinada igualmente a sufragar los gastos generados por los militares que estaban a su servicio ${ }^{63}$. Esta intere-

${ }^{56}$ García Fernández 2008.

${ }^{57}$ Szászdi 1999.

${ }^{58}$ AGS, CMC, 1a época, legajo 97.

${ }^{59}$ Ladero 2003, p. 106.

${ }^{60}$ Los continos que se encontraban al servicio de los reyes ejerciendo tareas diversas relacionadas con la administración regia apenas suponían un centenar de personas en toda Castilla en tiempos de los Reyes Católicos y procedían regularmente de familias hidalgas del reino. Véase Ladero 1998. Sobre los continos remito igualmente a Montero $2001 \mathrm{y}$ a la tesis doctoral de Rodríguez López 2006.

${ }^{61}$ García Fernández 2012c.

${ }^{62}$ Calderón 2013.

${ }^{63}$ Ladero 2003, p. 76. 
sante noticia presupone que este guipuzcoano llegó a contar con un notable crédito entre la Corona y los administradores generales de la hacienda regia castellana.

En 1499 los Reyes Católicos remitieron una provisión regia a las justicias de Vizcaya y de Guipúzcoa y a las villas de Laredo, Santander, Castro Urdiales, Valmaseda y San Vicente de la Barquera para que asistieran a García de Cotes, corregidor de Burgos, a Juan de Arbolancha y a Lope de Mújica en la recogida de las armas -bombardas y artillería- entregadas a los maestres de naos que formaron parte de la armada de la Archiduquesa con destino a Flandes. Estas armas las habían recibido previamente los maestres de nao de manos de Juan de Arbolancha y ahora se querían recuperar de forma expresa o en caso contrario su valor económico, aunque fuera necesario ejecutar embargos en sus bienes o en los de sus herederos ${ }^{64}$.

Ejercer de "contino" o de caballero elegido para servir en la Casa de Isabel I de Castilla fue consecuencia de la confianza depositada en Lope por gentes cercanas a la reina ${ }^{65}$. Sin duda, por su capacidad para llevar adelante negocios financieros, comerciales y militares promovidos desde la Corte. Uno de los momentos más culminantes de la progresión de Lope García de Mújica hacia las altas instancias de la administración regia se produjo entre 1499 y 1500. Por estos años Lope de Mújica fue designado capitán general de una armada compuesta por nueve naos, encargadas de portar armamento desde los puertos cantábricos a las ciudades de Málaga y Nápoles. El gasto de esta armada ascendió durante los tres primeros meses de 1500 a la cuantía de 3.301 .458 maravedíes $^{66}$. En 1498 el licenciado García Ibáñez de Mújica, su hermano, había sido designado miembro del Consejo Real. Entre 1505 y 1506, uno de los dos fieles del concejo de Villafranca de Ordicia, fue Lope García de Mújica ${ }^{67}$.

\section{UNA VISIÓN DE CONJUNTO}

Parece lógico sostener, en efecto, que los cargos y oficios a los que accedieron los miembros de la familia Mújica en los aparatos de poder del Estado y en otros ámbitos de la vida política están relacionados en el primer caso también con la influencia en la Corte de sus familiares, pero tampoco se puede

\footnotetext{
${ }^{64}$ García, Juan y Lope tuvieron capacidad de emitir cartas de pago a los maestres de nao o a sus herederos: AGS, RGS, legajo 1499, 10, 453.

${ }^{65}$ Szászdi 2000.

${ }^{66}$ Véanse Ladero 2003, p. 107; 2010, pp. 403-405; Ladero, Ladero 2002, pp. 93-95. Lope de Mújica ya en 1495 había sido enviado a Asturias a reclutar peones para la guerra de Nápoles.

${ }^{67}$ Irijoa 2006, p. 303; Aragón 2012b, p. 322.
} 
pasar por alto la presencia de otros guipuzcoanos en las esferas del poder político castellano, bien fueran "Parientes Mayores" ${ }^{68}$, gestores o financieros. Ciertamente no tenemos la seguridad al cien por cien de que contaran con el favor directo de dichos caballeros o de que su paisanaje con otros financieros guipuzcoanos fuera motivo suficiente de apoyo en los ámbitos económicos y cortesanos, aunque existen algunas pistas que pudieran redundar en dicho sentido. ¿Acaso los lazos familiares de los Mújica con los Lazcano ${ }^{69}$, Isa$\operatorname{saga}^{70}$ y Guevara ${ }^{71}$, familias con presencia o ascendencia en la Corte, se han de restringir exclusivamente a una cuestión de parentesco?

Desde el prisma de las relaciones matrimoniales se produjeron movimientos reseñables en el seno de la familia Mújica, tal como se desprende de lo señalado hasta este momento. Todo parece indicar que tuvieron algún tipo de parentesco con linajes solariegos principales de Vizcaya (los Mújica). El escudo de la familia guipuzcoana "denuncia" la procedencia del linaje vizcaíno de los Mújica. La banda terciada en dos escudetes fajados de tres fajas es un elemento constitutivo de las armerías de ambas familias. Y desde luego los Mújica emparentaron con otros linajes pudientes, los Bracamonte de Ávila y los Lazcano de Guipúzcoa ${ }^{72}$. A partir de fines del XV se produjeron

\footnotetext{
${ }^{68}$ Se ha escrito que los hijos del escribano García Ibáñez de Mújica fueron sobrinos de Juan Alonso de Mújica, uno de los "Parientes Mayores" más significativos del señorío de Vizcaya, miembro destacado del bando oñacino, cuyo máximo exponente en Guipúzcoa fue el linaje de la Casa de Lazcano: Rosa 1963.

${ }^{69}$ Martín de Mújica casó a fines del XV con Francisca de Lazcano, hija de Juan de Lazcano -señor de dicha casa solariega- y de doña Leonor de Zúñiga. Se ha señalado la influencia política de Leonor, pariente del obispo de Calahorra Diego de Zúñiga (1408-1443), que consiguió de Fernando el Católico un trato preferente para su familia. Sobresalen, sin embargo, las segundas nupcias de Bernardino de Lazcano con Beatriz de Cabrera, hija de Andrés de Cabrera, mayordomo de Enrique IV y marqués de Moya (Cuenca), y de Beatriz de Bobadilla, camarera de la reina Isabel. Familia de origen caballeresco que prosperó con Enrique IV y sobre todo con Isabel la Católica. De este modo Bernardino, cuñado del contador Martín de Mújica, contó en la Corte con unos apoyos capaces de conseguir que Juana y su marido Felipe el Hermoso fueran padrinos de uno de sus hijos, al que se pusieron por nombre Felipe en honor del borgoñón: Vasallo 2001.

${ }^{70}$ El comendador de la orden de Santiago, Ochoa Álvarez de Isasaga, era natural de Villafranca de Ordicia, del mismo pueblo que los Mújica. Ochoa fue un hombre de confianza de Fernando e Isabel de Castilla, así como tesorero y secretario de Doña María, hija de los Reyes Católicos, y reina de Portugal entre los años 1500 y 1509, al haberse casado con don Manuel I, rey de Portugal. Isasagas y Mújicas acabaron enlazando familiarmente.

${ }^{71}$ Nicolás de Guevara, comendador de la orden militar de Santiago, natural de la villa guipuzcoana de Segura, próxima a Villafranca, firma en 1489 como lugarteniente de contador mayor de cuentas de la Contaduría Mayor en la carta de finiquito de las alcabalas de Vitoria. Una nieta suya, María de Guevara, se desposó con el hijo primogénito de Martín de Mújica, llamado como el padre.

${ }^{72}$ Los Mújica vizcaínos y los Lazcano guipuzcoanos pertenecieron al bando oñacino. Lazcano y Mújica anudaron sus relaciones sociales concertando matrimonios entre las dos familias. En 1485 el Pariente Mayor de la Casa de Lazcano, Bernardino de Lazcano se casó en primeras nupcias con Elvira de Mújica, hija de Juan Alonso de Mújica.
} 
enlaces familiares de los Mújica de Villafranca con la Casa de Lazcano y con los Isasaga. Y el licenciado García Ibáñez de Mújica para principios del XVI ya estaba casado con Aldonza de Bracamonte, una de las pocas mujeres que sabía firmar por esa época.

En consecuencia, no es una simple coincidencia que se apelliden Mújica, como el linaje vizcaíno de la Casa de Mújica. Ni son accidentales el matrimonio de García Ibáñez de Mújica con Aldonza de Bracamonte, del contador Martín de Mújica a finales del XV con Francisca de Lazcano, hermana de Bernardino de Lazcano, señor de la casa solar de Lazcano, de su hijo llamado asimismo Martín de Mújica con María de Guevara en $1534^{73}$, de su nieta Francisca de Mújica con Juan López de Isasaga en $1548^{74}$, ni el de Juana de Mújica, la hija de Lope de Mújica, con Julián de Lazcano, uno de los hijos de Bernardino de Lazcano ${ }^{75}$. El casamiento de Bernardino de Lazcano, cuñado del contador, con una hija del marqués de Moya, bien posicionado en la Corte de Isabel la Católica, y las uniones familiares de los Mújica con Isasagas y Guevaras, entre cuyos miembros hubo gestores y financieros con un crédito considerable en la Corte, habrían de favorecer la reciprocidad de servicios, los nexos sociales y los apoyos mutuos. Ochoa Álvarez de Isasaga, tío de uno de los contrayentes, fue factor de la Casa de Contratación de Sevilla a principios del XVI y Nicolás de Guevara -nieto del conde de Oñate, Íñigo de Guevara-, abuelo de otro de los desposados, fue criado y teniente de mayordomo de Isabel la Católica. Se casó en segundas nupcias con Leonor de Avendaño, criada de la Casa de Isabel la Católica y en primeras con Gracia de Yarza, del solar de los Parientes Mayores de Yarza. Con esta última tuvo a su hijo primogénito, Juan Vélez de Guevara, contino de los Reyes Católicos, paje de la reina en 1497 y padre de María de Guevara, que casó con Martín de Mújica.

Estos lazos de parentesco fueron bien la culminación de un proceso previo de acuerdos o pactos de carácter sociopolítico, bien uno de los primeros puntos de partida para conseguir ese tipo de alianzas. En todos los casos

\footnotetext{
${ }^{73}$ Fueron testigos del contrato matrimonial, Felipe de Lazcano, señor del palacio de Lazcano, Juan López de Amézqueta, señor de Amézqueta, Yarza y Alcega, Juan Martínez de Verástegui, Ochoa Álvarez de Isasaga, etc. Martín de Mújica era dueño de la casa principal de la familia en Villafranca (la casa torre situada junto a la iglesia, de 4 caserías, de ganado, de la granja de Sajuela, (Burgos) y tenía dos juros de heredad, uno de 20.000 maravedíes en la villa de San Sebastián y otro de 6.000 en Cellorigo, Galbarruli, Sillanes y "Teudemuesto": ARChV, RE, 653, 10.

${ }^{74}$ Juan López hijo primogénito de Juan López de Isasaga, era sobrino del comendador Ochoa Álvarez de Isasaga, que estuvo presente en dicho acto: Archivo del Ayuntamiento de Ordizia, Pleitos Civiles, legajo 9, expediente 1.

${ }^{75} \mathrm{El}$ intercambio de favores familiares, personales y políticos entre los Lazcano y los Mújica parece bastante razonable.
} 
son una expresión de los intentos de reproducción y promoción social de la familia Mújica e igualmente de las otras. La institución familiar, como en otras poblaciones europeas, fue un elemento más en un complejo sistema de relaciones sociales ${ }^{76}$.

Los nuevos entresijos socio-familiares constatados en la primera mitad del XVI no deben hacernos olvidar que el escribano García Ibáñez de Mújica $^{77}$, el padre, había sido a mediados del siglo XV un acérrimo defensor de las hermandades guipuzcoanas frente a las aspiraciones de dominio de dos de los principales linajes de la tierra, los Lazcano y los Balda. En esta misma línea sus hijos se implicaron a fines del siglo XV y a principios del XVI en la vida política de la villa de Villafranca de Ordicia y en las instituciones provinciales (las Juntas Generales de Guipúzcoa). Paralelamente comenzaron a tejer sus redes de parentesco con linajes tradicionales de caballeros como los Lazcano y con familias de hidalgos guipuzcoanos, Nicolás de Guevara y Ochoa Álvarez de Isasaga, con peso en la Corte ${ }^{78}$. Por estas fechas también tenía una relevancia particular en la Corte castellana Juan López de Lazárraga ${ }^{79}$.

Los datos históricos disponibles apuntan a que García Ibáñez de Mújica, padre, procediendo con acierto en sus actitudes políticas, puso los fundamentos del futuro despegue socio-político de su familia. Al menos cuatro de sus hijos desempeñaron un papel destacado en la Corte o en la Casa de los reyes o infantes castellanos a fines del siglo XV y principios del XVI. Con toda seguridad, dicha realidad resulta difícil de explicar, a no ser que se contemple la importancia de las redes sociofamiliares de los Mújica y la elevada conciencia de pertenencia e identidad familiar ${ }^{80}$, resortes y palancas de sus miembros, susceptibles de haber sido utilizados de una u otra manera para lograr una influencia política considerable en Villafranca de Ordicia y en la provincia de Guipúzcoa, así como para llegar a ocupar posiciones destacadas en la Corte regia y su entorno.

\footnotetext{
${ }^{76}$ Tabbagh 1994, p. 258; Casey, Hernández 1997.

${ }^{77}$ En 1502 su nieto Juan Ibáñez de Mújica le sustituyó en la escribanía del número del concejo de Villafranca.

${ }^{78}$ Véanse García Fernández 2012b; Hernández 2003.

${ }^{79}$ Ya en 1498, Juan López de Lazárraga, vecino de Oñate, persona con estrechas relaciones con los miembros del linaje de la casa de Guevara, señores de Oñate y con el influyente contador mayor de cuentas Gutierre de Cárdenas, es citado en la documentación escrita como lugarteniente de contador mayor: Sánchez de Rivera 1984; Castro 1992; AGS, RGS, IV-1498-30. Juan López de Lazárraga, estaba bien posicionado en la Corte, fue secretario del rey Fernando el Católico, contador de la reina Isabel y uno de los albaceas testamentarios de esta última. Se casó dos veces, con mujeres de linajes guipuzcoanos, los Murguía de Oñate y los Gamboa, señores de Olaso. Tuvo un hijo con la primera y una hija con la segunda. El primero murió a los tres años y la segunda antes de 1527, lo que pudo favorecer el patronazgo en la Corte de varones de otras familias guipuzcoanas con quienes se relacionaba. Falleció en 1516. Lanzagorta 2004.

${ }^{80}$ Dacosta 2007; Beceiro, Córdoba de la Llave 1990.
} 
No nos han quedado noticias de correspondencia letrada entre los hermanos, pero sí del paso de documentación elaborada por uno de ellos a los demás. Un pequeño libro de cuentas de los salarios pagados a los hombres de a pie que acompañaron a Miguel de Mújica a la conquista de Gran Canaria pasó a su muerte a su hermano Lope y después a manos de Martín, según la cuenta de Antonio de Arévalo de $1495^{81}$. En Villafranca de Ordicia aún pueden verse huellas de la casa torre de los Mújica, pero es sobre todo en el palacio renacentista de García Ibáñez de Mújica en Ávila donde se aprecian los signos y símbolos de identidad de la familia, en varios escudos familiares.

Desde luego las redes familiares y clientelares tuvieron un papel determinante en la evolución política castellana y en bastantes ocasiones sirvieron de palanca de promoción social y política. Lope García de Mújica llegó a ser uno de los "continos" de la Casa Real castellana. Su selección para servir a los Reyes Católicos fue el colofón de su ascenso social y político en el conjunto del Reino, pues el número de estos "oficiales" era muy reducido en toda la Corona. Los Reyes Católigos le pusieron al frente de empresas de envergadura promovidas por la Corte castellana. Martín de Mújica llegó a ser uno de los oficiales de la Contaduría Mayor de Cuentas, fue maestresala de la reina Isabel la Católica y mantuvo unas buenas relaciones con Fernando el Católico, que le envió como embajador a Inglaterra para tratar con Enrique VIII sobre la guerra con Francia.

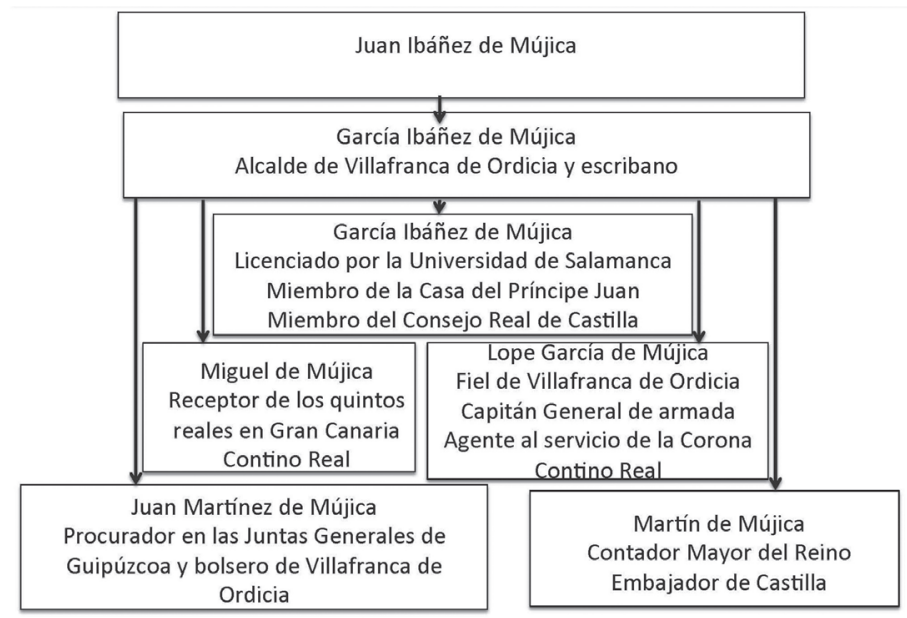

Cuadro 2. Cargos en la administración y representación política de la familia Mújica de Villafranca de Ordicia a fines de la Edad Media.

\footnotetext{
${ }^{81}$ Ladero 1966, pp. 66-68.
} 
Está documentado que el padre de ambos, el escribano García Ibáñez de Mújica y Miguel de Mújica, su otro hermano, "contino" antes que Lope de Mújica, cooperaron respectivamente con el pesquisidor Bartolomé de Zuloaga y con el contador mayor de cuentas Rodrigo de Ulloa. Es relevante el hecho de que otro hermano suyo, el licenciado García Ibáñez de Mújica -formado en la Universidad de Salamanca donde obtuvo el título de Licenciado-, fuera miembro del Consejo de la Casa del Príncipe Juan y posteriormente del Consejo del Reino. Sus descendientes dispusieron de una capilla en la catedral de Ávila y gustaron de la pintura del Greco. En la capilla del Cardenal se halla uno de los retratos del Greco, el de García Ibáñez de Mújica, casado con María de Velasco del Águila y probablemente nieto del licenciado Mújica.

La promoción social de la familia Mújica no puede desligarse de la proximidad a la Corte de una parte de sus miembros: "continos", servidores de las casas de los reyes y de los infantes, contadores, embajadores y miembros del Consejo Real. Esta cercanía a los reyes e infantes, reservada a un núcleo bastante limitado de personas, primaba directa o indirectamente las preeminencias sociales de una familia de la nobleza castellana no titulada y reforzaba unas determinadas redes clientelares sustentadas en la existencia de unas jerarquías sociales, cuya plasmación no estuvo al margen de un lado de la fortuna mayor o menor de sus miembros y de otro de las redes de patronazgo y sociales establecidas a lo largo de los años ${ }^{82}$. Los lazos establecidos entre la administración regia y los Mújica se materializaron en la percepción de rentas diversas a cambio de su servicio y fidelidad a la monarquía ${ }^{83}$, pero que igualmente llevaron aparejada la transferencia de otro tipo de ventajas relacionadas con el honor y el prestigio social derivados de su participación en los aparatos centrales de la Corona de Castilla ${ }^{84}$. Del mismo modo, sus relaciones comerciales con los poderosos Velasco, de quienes fueron recaudadores de los diezmos de la mar en Guipúzcoa, debieron reforzar su preeminencia en el territorio $^{85}$.

\footnotetext{
${ }^{82}$ Chacón, Bestard 2011, p. 25.

${ }^{83}$ Mousnier 1972.

${ }^{84}$ Clavero 1996; Martínez, Ezquerra 2002, pp. 340-341.

${ }^{85}$ Díez de Salazar 1983, vol. 2, p. 257.
} 


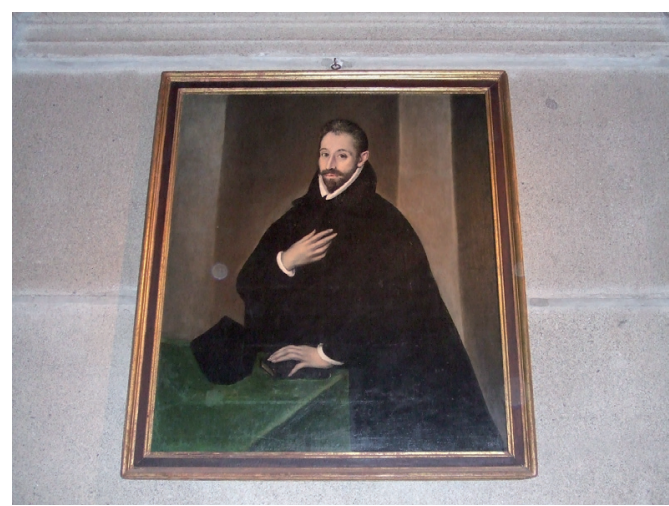

Fig. 6. Retrato de García Ibáñez de Mújica y Bracamonte, descendiente de García Ibáñez de Mújica, miembro del Consejo Real.

La pintura ubicada en la catedral de Ávila se atribuye a "El Greco".

Por el contrario, Juan Martínez de Mújica, bolsero del concejo de Villafranca de Ordicia en cuatro ocasiones, circunscribió sobre todo su protagonismo político al entorno local y provincial. Ahora bien hay un hecho notorio que no se ha de pasar por alto. Los representantes de la Provincia, siendo Juan uno de los procuradores reunidos en las Juntas Generales de Guipúzcoa celebradas el 15 de febrero de 1508 en Vidania, nombraron a Lope Martínez de Olaberría para negociar el encabezamiento perpetuo de alcabalas con su alteza la reina Juana, un derecho fiscal también añorado esos mismos años por los dirigentes de la Provincia de Álava. La consecución de la carta de provisión regia que reconocía el encabezamiento a perpetuidad de las alcabalas de la Provincia de Guipúzcoa coincidió con el periodo de tiempo en que el licenciado García Ibáñez de Mújica y Martín de Mújica, hermanos de Juan, fueron respectivamente miembros del Consejo Real y Contador Mayor. En este sentido, tampoco se ha de descartar que algunos componentes de la familia Mújica hubieran podido estar directa o indirectamente involucrados en la promoción en la Corte del programa de reivindicación política, administrativa y fiscal auspiciado desde la Provincia de Guipúzcoa. Acaso Juan Martínez de Mújica pudo haberse constituido coyunturalmente en una correa de transmisión de los intereses de la Provincia en la Corte a través de sus hermanos. Asimismo quiero reflejar que la formación del Consulado de Bilbao se produjo siendo el licenciado García Ibáñez de Mújica miembro del Consejo Real. En este sentido pudiera ser de interés investigar todas las fórmulas empleadas por los procuradores de Bilbao para conseguir la provisión regia otorgada por la reina Juana. 


\section{CONCLUSIONES}

No se trata ahora de reproducir cuestiones ya señaladas en los apartados anteriores, no tiene mucho sentido recordar los interrogantes formulados en la introducción, ni desarrollar las ideas centrales que estructuran los argumentos de los epígrafes del estudio, ni reiterar los puestos desempeñados o las ocupaciones encomendadas a la familia Mújica en la administración regia y su entorno. Bien al contrario quiero finalizar resaltando cinco puntos que configuran y forman parte del marco metodológico del estudio:

El primero de ellos alude a la constatación de que estamos en presencia de una nobleza cortesana e hidalga que se procura cargos y rentas por su servicio a la monarquía, aunque también prestigio, consideración y honor.

El segundo se refiere a que los Mújica, con una provechosa colocación en la Corte y siendo una pieza más en el puzzle de la administración regia castellana, no lograron conformar en la Edad Media los tradicionales señoríos nobiliarios, al contrario que otros personajes ${ }^{86}$, si bien el licenciado García Ibáñez de Mújica y el contador Martín de Mújica contrajeron matrimonio con hijas de señores de vasallos. El primero con una hija del linaje Bracamonte, señores de Fuente el Sol (Valladolid) y el segundo con una hija del linaje de la Casa de Lazcano, cuyos "Parientes Mayores" fueron señores de la villa de Contrasta y del valle de Arana (Álava).

El tercero pone de relieve que estos hidalgos, naturales de núcleos urbanos, tuvieron intereses específicos y en este sentido diferenciadores de otras familias caballerescas castellanas.

El cuarto acentúa la imagen de que un grupo muy selecto de hidalgos castellanos, con buenos contactos con miembros de la Corte y con una formación letrada adquirida por entrar al servicio de otros oficiales de la administración regia o por haber estudiado en la universidad, sobresalieron entre la pléyade reducida de cortesanos, incluso por encima de caballeros, señores de vasallos, cuyo acceso no llegó a producirse a la Casa y Corte reales.

Y el quinto recalca que la promoción de estos hidalgos, acomodados desde un punto de vista económico y social, estuvo muy relacionada con su competencia administrativa y gestora, porque el acceso al poder es un proceso en construcción que requiere eficacia y liderazgo, además de servicio y fidelidad. De ahí la confianza depositada en estos hidalgos por los Reyes

\footnotetext{
${ }^{86}$ Por ejemplo Pedro Carrillo de Huete, Gutierre de Cárdenas y Juan Manuel o Andrés de Cabrera; Quintanilla 2011.
} 
Católicos ${ }^{87}$ y por los Velasco, condestables de Castilla. Desde esta perspectiva los cometidos de esta "nobleza menor" fueron determinantes en el desarrollo y configuración de la Corte y en la construcción de los estados bajomedievales. El parentesco de consanguinidad y matrimonial, en fin, no fueron los únicos medios de procurar el encumbramiento social y político.

En suma, creo que este artículo tiene la virtud de sacar a la luz pública los entramados socio-familiares y político-administrativos de familias hidalgas, que merecen estudios específicos sobre su protagonismo en las esferas de la Corte. Entiendo que la función y el ascendiente de la pequeña nobleza urbana castellana en el tejido institucional de la administración regia no deben ser postergados.

\section{BIBLIOGRAFÍA CITADA}

Aragón Ruano, Álvaro (2011), Administración financiera local en Guipúzcoa entre 1450 y 1520, "Boletín de Estudios Históricos de San Sebastián” 44, pp. 77-155.

Aragón Ruano, Álvaro (2012a), Linajes urbanos y Parientes Mayores en Guipúzcoa a finales de la Edad Media (1450-1520), "En la España Medieval" 35, pp. 249-283.

Aragón Ruano, Álvaro (2012b), Prosopografía de los recaudadores municipales de Guipúzcoa en los inicios del siglo XVI (1500-1520), en Galán Sánchez, Ángel; García Fernández, Ernesto (eds.), En busca de Zaqueo: los recaudadores de impuestos en las épocas medieval y moderna, Madrid, Instituto de Estudios Fiscales, pp. 313-335.

Arocena Echeverría, Ignacio (1981), Linajes, Bandos y Villas, en Caro Baroja, Julio (dir.), Historia General del País Vasco, San Sebastián, Haranburu, pp. 9-124.

Aurell, Martín (ed.) (2010), La Parenté déchirée: les luttes intrafamiliales au Moyen Âge, Turnhout, Brepols.

Ayerbe Iríbar, María Rosa; San Miguel Osaba, Ana (2013), Archivo Municipal de Ataun (1268-1519), San Sebastián, Sociedad de Estudios Vascos.

Beceiro, Isabel (1995), Parentesco y consolidación de la aristocracia en los inicios de la Corona de Castilla (s. XI-XIII), "Meridies” 2, pp. 49-71.

\footnotetext{
${ }^{87}$ También se dio este fenómeno en otros reinos cristianos europeos. Para Portugal véase Pereira 2003, vol. I, pp. 135-141. Este autor afirma que en su origen la Corte se nutrió sobre todo de una "aristocracia rural" que diversificó sus funciones, competencias y formas de vida.
} 
Beceiro, Isabel; Córdoba de La Llave, Ricardo (1990), Parentesco, poder y mentalidad. La nobleza castellana, siglos XII-XV, Madrid, Consejo Superior de Investigaciones Científicas.

Blázquez Mayoral, Fernando (2010), Estructuras familiares y gestión patrimonial. El ejemplo del linaje Cárdenas, Madrid, Universidad Complutense (trabajo inédito de tercer ciclo).

Cabello, Claudio (1977), Tamaran. Aproximación elemental a la Historia y geografía de Gran Canaria, Las Palmas, Imprenta Pérez Galdós.

Calderón Ortega, José Manuel (2013), El almirantazgo de Castilla. Historia de una institución conflictiva (1250-1560), Alcalá de Henares, Universidad de Alcalá de Hernares.

Carvajal de la Vega, David; Añíbarro Rodríguez, Javier; Vítores Casado, Imanol (eds.) (2012), Redes sociales y económicas en el mundo bajomedieval, Valladolid, Castilla Ediciones.

Cascales, Francisco (1775), Discursos históricos de la muy noble i mui leal ciudad de Murcia y su reino, Murcia, Francisco Benedito.

Casey, James; Hernández Franco, Juan (1997), Familia, parentesco y linaje. Seminario Familia y elites de poder en el Reino de Murcia, siglos XVXIX, Murcia, Universidad de Murcia.

Castro y Castro, Manuel de (1992), Teresa Enríquez, la loca del Sacramento y Gutierre de Cárdenas, Toledo, Instituto Provincial de Investigaciones y Estudios Toledanos.

Chacón, Francisco; Bestard, Jean (dirs.) (2011), Familias. Historia de la sociedad española (del final de la Edad Media a nuestros días), Madrid, Cátedra.

Clavero, Bartolomé (1996), La grâce du don, París, Albin Michel.

Cos, Peter (1995), The Knight in Medieval England. 1000-1400, Gloucestershire, Phoenix Mill.

Dacosta Martínez, Arsenio Fernando (1997), El hierro y los linajes de Vizcaya en el siglo XV: fuentes de renta y competencia económica, "Studia Historica. Historia Medieval" 15, pp. 69-102.

Dacosta Martínez, Arsenio Fernando (1999), De dónde sucedieron unos en otros. La historia y el parentesco vistos por los linajes vizcainos bajomedievales, "Vasconia" 28, pp. 57-70.

Dacosta Martínez, Arsenio (2003), Los linajes de Bizkaia en la Baja Edad Media: poder, parentesco y conflicto, Bilbao, Universidad del País Vasco.

Dacosta Martínez, Arsenio (2007), El libro del linaje de los Señores de Ayala y otros textos genealógicos: materiales para el estudio de la conciencia del linaje en la Baja Edad Media, Bilbao, Universidad del País Vasco. 
Davis, Isabel; Muller, Miriam; Rees Jones, Sarah (eds.) (2003), Love, Marriage and Family Ties in the Later Middle Ages, Turnhout, Brepols (International Medieval Research; 11).

Díaz de Durana José Ramón (ed.) (1998), La Lucha de Bandos en el País Vasco: de los parientes mayores a la hidalguía universal. Guipúzcoa, de los bandos a la Provincia (siglos XIV a XVI), Bilbao, Universidad del País Vasco.

Díaz de Durana José Ramón (2004), La otra nobleza. Escuderos e hidalgos sin nombre y sin historia. Hidalgos e hidalguía universal en el País Vasco al final de la Edad Media (1250-1525), Bilbao, Universidad del País Vasco.

Díaz de Durana Ortiz de Urbina, José Ramón (2009), La familia en la cornisa cantábrica al final de la Edad Media, en Lorenzo Pinar, Francisco Javier (coord.), La familia en la Historia, Salamanca, Universidad de Salamanca, pp. 63-88.

Díez de Salazar Fernández, Luis Miguel (1983), Ferrerías en Guipúzcoa (siglos XIV-XVI). Fuentes e Instituciones, vol. 2, San Sebastián, Haranburu editor.

Díez de Salazar Fernández, Luis Miguel (1997), Ferrerías guipuzcoanas: aspectos socio-económicos, laborales y fiscales (siglos XIV-XVI), San Sebastián, Fundación social y cultural Kutxa.

Duby, Georges (ed.) (1988), De la Europa feudal al Renacimiento, vol. 2, Madrid, Taurus.

Estornés Lasa, Bernardo (Fondo), Entziklopedia Auñamendi, URL: www.euskomedia.org, [consulta: 02/01/14].

Fernández de Córdova Miralles, Álvaro (2002), La Corte de Isabel I (14741504): ritos y ceremonias de una reina, Madrid, Dykinson.

Fernández de Córdova Miralles, Álvaro (2004), Sociedad cortesana y entorno regio, "Medievalismo. Boletín de la Sociedad Española de Estudios Medievales" 13-14, pp. 49-78.

Fernández de Oviedo, Gonzalo (2006), Libro de la Cámara Real del Príncipe don Juan, oficios de su Casa y servicio ordinario, Valencia, Universidad de Valencia.

Framiñán Santas, Ana María; Presedo Garazo, Antonio (2005), Estructuras de parentesco de la nobleza gallega en 1350-1600: una primera valoración, "Obradoiro de Historia Moderna" 14, pp. 109-140.

Franco Silva, Alfonso (1986-1987), El mariscal Álvaro de Ávila y los orígenes del Conado de Peñaranda, "Estudios de Historia y de arqueología medievales" 5-6, pp. 215-238.

Galdos Monfort, Ana (2008), De Villafranca a Ordizia. Un camino pleno de historia, Ordizia, Ayuntamiento de Ordizia. 
García de Valdeavellano, Luis (1970), Curso de Historia de las instituciones españolas: de los orígenes al final de la Edad Media, Madrid, Alianza Editorial.

García Fernández, Ernesto (2004), Gobernar la ciudad en la Edad Media: oligarquías y elites urbanas en el País Vasco, Vitoria, Diputación Foral de Álava.

García Fernández, Ernesto (2007a), El linaje Avendaño: causas y consecuencias de su ascenso social en la Baja Edad Media, "Anuario de Estudios Medievales" 37/2, pp. 527-561.

García Fernández, Ernesto (2007b), El linaje del Canciller don Pero López de Ayala, en El linaje del Canciller Ayala, Vitoria, Diputación Foral de Álava, pp. 80-335.

García Fernández, Ernesto (2007c), Fortuna y poder de un linaje medieval: Los Avendaño, señores de Villarreal de Álava, en Micaela Portilla Omenaldia. Homenaje In Memoriam. Separata. Kongresu Jardunaldien Aktak. Actas de las Jornadas Congresuales. Otsailak 21, 22, 23 eta 24.21, 22, 23 y 24 de febrero de 2007, Vitoria, Diputación Foral de Álava, pp. 71-84.

García Fernández, Ernesto (2008), El linaje de la Casa de Murga en la historia de Álava (siglos XIV-XVI), Vitoria, Diputación Foral de Álava.

García Fernández, Ernesto (2009a), La Casa de Guevara en la Edad Media: poder y conflicto en las tierras de un linaje señorial, en Val Valdivieso, María Isabel del; Martínez Sopena, Pascual (dirs.), Castilla y el mundo feudal. Homenaje al profesor Julio Valdeón, Valladolid, Junta de Castilla y León, Consejería de Cultura y Turismo - Universidad de Valladolid, pp 387-405.

García Fernández, Ernesto (2009b), La Hacienda medieval en Álava, Guipúzcoa y Vizcaya, "Iura Vasconia" 6, pp. 275-338.

García Fernández, Ernesto (2010a), Acerca de la contribución militar de la Junta General de la Provincia de Guipúzcoa a la guerra de Granada en 1484, "Anuario de Estudios Medievales" 40/2, pp. 617-642.

García Fernández, Ernesto (2010b), Los cuadernos de las rentas del rey en el Archivo Municipal de Vitoria: los finiquitos del pedido y de las alcabalas del concejo de Vitoria (1476-1526), en Collantes de Terán, Antonio (ed.), Fuentes para el estudio del negocio fiscal y financiero en los Reinos hispánicos (siglos XIV-XVI), Madrid, Instituto de Estudios Fiscales, pp. 95-117.

García Fernández, Ernesto (2012a), Hacienda y fiscalidad en el País Vasco y La Rioja a finales de la Edad Media, en Goicolea Julián, Francisco 
Javier; García Fernández, Ernesto (eds.), Las haciendas medievales en el País Vasco y La Rioja. Textos para su estudio, Madrid, Instituto de Estudios Fiscales, pp. 11-82.

García Fernández, Ernesto (2012b), Hombres y mujeres de negocios del país Vasco en la Baja Edad Media, en Bonachía Hernando, Juan Antonio; Carvajal de la Vega, David (eds.), Los negocios del hombre. Comercio y rentas en Castilla (siglos XV y XVI), Valladolid, Castilla Ediciones, pp. 101-140.

García Fernández, Ernesto (2012c), La tesorería de Diego Martínez de Maeztu en Álava y Guipúzcoa en época de Isabel la Católica, en García Fernández, Ernesto; Vítores Casado, Imanol (eds.), Tesoreros, arrendadores y financieros en los reinos hispánicos: la Corona de Castilla y el Reino de Navarra (siglos XIV-XVII), Madrid, Instituto de Estudios Fiscales, pp. 161-194.

García Fernández, Ernesto (2013), Alcabalas y gasto público en Guipúzcoa y Álava a fines de la Edad Media, en Carretero Zamora, Juan; Galán Sánchez, Ángel (eds.), El alimento del estado y la salud de la "res publica": orígenes, estructura y desarrollo del gasto público en Europa, Madrid, Instituto de Estudios Fiscales, pp. 309-340.

García Marín, José María (1987), El oficio público en Castilla, Madrid, Instituto Nacional de Administración Pública.

Gerbet, Marie-Claude (1994), Les Noblesses Espagnoles au Moyen Âge, XI ${ }^{e}$ $X V^{e}$ siècle, París, Armand Colin.

Gerbet, Marie-Claude (1997), Las noblezas españolas en la Edad Media, ss. XI-XV, Madrid, Alianza Editorial.

Goicolea Julián, Francisco Javier; García Fernández, Ernesto (eds.) (2012), Las haciendas medievales en el País Vasco y La Rioja. Textos para su estudio, Madrid, Instituto de Estudios Fiscales.

Goody, Jack (1983), The development of the family and marriage in Europe, Cambridge, Cambridge University Press.

Gorosábel, Pablo (1862), Diccionario Geográfico-Descriptivo de los Pueblos, Valles, Partidos, Alcaldías y Uniones de Guipúzcoa, Tolosa, Imprenta de Pedro Gurruchaga.

Guerra, Juan Carlos (1908-1912), Esteban de Garibay y Zamalloa: Ilustraciones genealógicas de los linajes bascongados contenidos en las grandezas de España, "Revista Internacional de Estudios Vascos" 2, pp. 535-563; 3, pp. 110-120, 436-455; 4, pp. 48-58, 394-418; 5, pp. $58-85 ; 6$, pp. 201-223.

Guevara, Fr. Antonio de (1994), Relox de Príncipes, estudio y edición de Emilio Blanco, Madrid, ABL editor (primera edición, Valladolid 1529). 
Heers, Jacques (1974), Le clan familial au Moyen Âge. Étude sur les structures politiques et sociales des milieux urbains, París, Presse Universitaires de France.

Hernández Sánchez-Barba, Mario (2003), El doctor Sancho de Matienzo, la Casa de Contratación y Villasana de Mena, "Mar océana. Revista del Humanismo Español e Iberoamericano" 14-15, pp. 43-63.

Irijoa Cortés, Iago (2006), Gipuzkoa, "So color de Comunidad". Conflicto político y constitución provincial a inicios del siglo XVI, Donostia - San Sebastián, Diputación Foral de Guipúzcoa, URL: http://www.artxibogipuzkoa.gipuzkoakultura.net/libros-e-liburuak/bekak-becas04. pdf [consulta: 01/06/2014].

Ladero Quesada, Miguel Ángel (1966), Las cuentas de la conquista de Gran Canaria, "Anuario de Estudios Atlánticos" 12, pp. 11-104.

Ladero Quesada, Miguel Ángel (1998), La Casa Real en la Baja Edad Media, "Historia, Instituciones, Documentos" 25, pp. 327-350.

Ladero Quesada, Miguel Ángel (2001), La "Armada de Vizcaya” (14921493): nuevos datos documentales, "En la España Medieval” 24, pp. 365-394.

Ladero Quesada, Miguel Ángel (2003), La armada de Flandes. Un episodio en la política naval de los Reyes Católicos (1496-1497), Madrid, Real Academia de la Historia.

Ladero Quesada, Miguel Ángel (2007), La Financiación de la Guerra por la monarquía castellana 1252-1515, "Revista de Historia Militar" núm. extraordinario: La guerra y su financiación (Baja Edad Media y Edad Moderna), pp. 13-38.

Ladero Quesada, Miguel Ángel (2010), Ejércitos y armadas de los Reyes Católicos. Nápoles y el Rosellón 1494-1504, Madrid, Real Academia de la Historia.

Ladero Galán, Aurora; Ladero Quesada, Miguel Ángel (2002), Ejércitos y armadas de los Reyes Católicos: algunos presupuestos y cuentas de gastos entre 1493 y 1500, "Revista de Historia Militar" 92, pp. 43-110.

Lanzagorta Arco, María José (2004), El linaje de los Lazárraga: siblos XVXVI en el Condado de Oñate (Guipúzcoa), "Sancho el Sabio. Revista de Cultura e Investigación Vasca" 20, pp. 71-86.

Lema, José Angel; Fernández de Larrea, Jon Andoni; García, Ernesto; Larrañaga, Miguel; Munita, José Antonio; Díaz de Durana, José Ramón (2002), El triunfo de las elites urbanas guipuzcoanas: nuevos textos para el estudio del gobierno de las villas y de la Provincia (14121539), San Sebastián, Diputación Foral de Guipúzcoa.

Lobo Cabrera, Manuel (2012), La conquista de Gran Canaria (1478-1483), Las Palmas de Gran Canaria, Ediciones del Cabildo de Gran Canaria. 
Marín Paredes, José Antonio (1998), ¿Qué es un Pariente mayor? El ejemplo de los señores de Oñaz y Loyola, en Díaz de Durana, José Ramón (ed.), La lucha de bandos en el País Vasco, de los Parientes Mayores a la Hidalguía Universal: Guipúzcoa, de los bandos a la Provincia (siglos XIV-XVI), Bilbao, Universidad del País Vasco, pp. 297-234.

Martínez Millán, José; Ezquerra Revilla, Javier (2002), La integración de las elites sociales en las monarquías dinásticas: los continos, en Espacios de poder: cortes, ciudades y villas ( $s$. XVI-XVIII), Madrid, Universidad Autónoma, vol. 1, pp. 339-380.

Mattoso, José (ed.) (1994), A Nobreza medieval portuguesa: A familia e o poder, Lisboa, Editorial Estampa.

Maczak, Antoni (1996), Nécessité et complexité des relations entre État et noblesse, en Reinhard, Wolfgang (dir.), Les élites du pouvoir et la construction de l'État en Europe, París, Presses Universitaires de France, pp. 259-283.

Molina Puche, Sebastián; Irigoyen López, Antonio (eds.) (2009), De familias, redes y elites de poder: una introducción crítica, en Molina Puche, Sebástián; Irigoyen López, Antonio (coords.), Territorios distantes, comportamientos similares. Familias, redes y reproducción social en la Monarquía Hispánica (siglos XIV-XIX), Murcia, Universidad de Murcia, pp. 9-22.

Monsalvo Antón, José María (1993), Parentesco y sistema concejil. Observaciones sobre la funcionalidad política de los linajes urbanos en Castilla y León, "Hispania" 53/3, pp. 937-969.

Montero Tejada, Rosa María (2001), Los continos "hombres de armas" de la Casa Real castellana (1495-1516): una aproximación de conjunto, "Boletín de la Ral Academia de la Historia" 198/1, pp. 103-130.

Moreno Ollero, Antonio; Franco Silva, Alfonso (1990-1991), Las primeras ordenanzas municipales de Villena (1440-1445), "Anales de la Universiad de Alicante: Historia Medieval" 8, pp. 115-145.

Mousnier, Roland (1972), Les concepts d'ordres, d'états, de fidelité et de monarchie absolute en France de la fin du XV siècle à la fin du XVIII ${ }^{e}$, "Revue Historique" 502, pp. 289-312.

Múgica Zufiría, Serapio (1918a), Geografía de Guipúzcoa, en Carreras Candi, Francisco, Geografía General del País Vasco-Navarro, vol. 5, Barcelona, Editorial Alberto Martín.

Múgica Zufiria, Serapio (1918b), Geografía de Guipúzcoa. Villafranca de Oria [en línea], San Sebastián, URL: http://www.ingeba.org/klasikoa/geografi/mug303/g987995.htm [consulta: 01/04/2014].

Munita Loinaz, José Antonio; Dacosta, Arsenio; Lema Pueyo, José Ángel; Paz Moro, Agurtzane; Díaz de Durana, José Ramón (2014), “En tiempo 
de ruidos y bandos". Nuevos textos para el estudio de los linajes vizcainos: los Barroeta de la Merindad de Marquina (1355-1547), Bilbao, Universidad del País Vasco.

Muñoz Gómez, Víctor (2009), La participación política de las elites locales en el gobierno de las ciudades castellanas en la Baja Edad Media. Bandos y conflictos de intereses (Paredes de Nava, final del s. XIVinicio del s. XV), "Anuario de Estudios Medievales" 39/1, pp. 275305.

Pardo de Guevara y Valdés, Eduardo (1985), Los Castro gallegos del siglo XIV. Apuntes para un análisis de su proyección en la historia política de Castilla, "Hispania" 45, pp. 477-511.

Pardo de Guevara y Valdés, Eduardo (2012), Identidad y memoria genealógica. Una aportación al estudio de la antroponimia medieval gallega, en Idem, De linajes, parentelas y grupos de poder. Aportaciones a la historia social de la nobleza bajomedieval gallega, Madrid, Alberdi, pp. 71-94.

Parrado del Olmo, José María (1981), La capilla de Mosén Rubí de Bracamonte, "Boletín del Seminario de Arte y Arqueología" 47, pp. 285-306.

Pereira, António Dos Santos (2003), Portugal o império urgente (1475-1525). Os espaços, os homens e os produtos, vol. I, Lisboa, Imprenta Nacional - Casa da Moeda.

Pérez Bustamante, Rogelio (1976), El gobierno y la administración de los reinos de la Corona de Castilla: 1230-1474, Madrid, Ediciones Aldecoa.

Pérez de Tudela Bueso, Juan (1973), La Armada de Vizcaya. Acerca de una razón de fuerza y otros argumentos en el acuerdo de Tordesillas, en El tratado de Tordesillas y su proyección. Actas I Coloquio lusoespañol de Historia Ultramarina, Valladolid, Universidad de Valladolid, vol. I, pp. 32-92.

Pulgar, Fernando del (1943), Crónica de los Reyes Católicos, Madrid, Espasa Calpe.

Quintanilla Raso, María Concepción (2011), Consejeros encumbrados. El Consejo Real y la promoción de la nobleza castellana en el siglo XV, "e-Spania" 12 [en línea], URL: http://e-spania.revues.org/20680 [consulta: 20/11/2013].

Rodríguez López, Inés (2006), Los continos de la Casa Real durante el Reinado de los Reyes Católicos, Valladolid, Universidad de Valladolid (tesis doctoral).

Rodríguez Lozano, José Antonio; Malpica Coello, Antonio (1982), La alquería de Cázulas y la tierra de Almuñecar a finales del siglo XV: notas 
y documentos para su estudio, "Estudios de Historia y de Arqueología Medievales" 2, pp. 71-92.

Rodríguez Muñoz, Pedro (1951), Un colaborador de los Reyes Católicos: Miguel Pérez de Almazán, "Publicaciones de la Institución Tello Téllez de Meneses" 6, pp. 117-158.

Rosa Olivera, Leopoldo de la (1963), Linaje y descendencia de don Antonio de Vera Múxica, refundador de Santa Fé en el Río de la Plata, "Anuario de Estudios Atlánticos" 9, pp. 81-119.

Salazar Acha, Jaime (2000), La Casa del Rey de Castilla y León en la Edad Media, Madrid, Centro de Estudios Políticos y Constitucionales.

Sánchez de Rivera, Gonzalo (1984), Don Gutierre de Cárdenas, señor de Torrijos (Materiales para una biografía), Toledo, Diputación Provincial de Toledo.

Szászdi León-Borja, István (1999), El origen de la Armada de Vizcaya y el Tratado de Alcáçovas, "Historia, Instituciones y Documentos" 26, pp. 547-574.

Szászdi León-Borja, István (2000), Los continos de don Cristóbal Colón, "Espacio, Tiempo y Forma. Historia Medieval" 13, pp. 397-420.

Szászdi León-Borja, István (2003), La resistencia foral vizcaína a la política castellana marítima en la era de los descubrimientos, "Notitia Vasconiae. Revista de Derecho Histórico de Vasconia" 2, pp. 381-411.

Tabbagh, Vincent (1994), Famille et société: l'exemple de Rouen au XV siècle, en Desportes, Pierre (dir.), Villes et sociétés urbaines au Moyen Âge. Mélanges en l'honneur de Jacques Heers, París, Université de Paris Sorbonne, pp. 247-258.

Torres Sanz, David (1982), La administración central castellana en la Baja Edad Media, Valladolid, Universidad de Valladolid.

Urteaga, María Mercedes (1996), Siderurgia medieval en Guipúzcoa: haizeolas, ferrerías masuqueras y ferrerías mazonas, en Actas de las I Jornadas sobre Minería y Tecnología en la Edad Media Peninsular: León, 26-29 de septiembre de 1995, León, Fundación Hullera Vasco-Leonesa, pp. 543-554.

Vasallo Toranzo, Luis (2001), Los Lazcano y su casa fuerte de Contrasta en Álava, "Ondare. Cuadernos de Artes Plásticas y Monumentales" 20, pp. 241-258.

Fecha de recepción del artículo: mayo 2014

Fecha de aceptación y versión final: mayo 2015 